\title{
JUDICIAL SUPREMACY AND THE STRUCTURE OF PARTISAN CONFLICT
}

\author{
MARK A. GRABER*
}

American progressives are rekindling their love affair with federal judicial power. The American left during the 1960s and early 1970s was smitten by a Supreme Court that protected political dissenters, racial minorities, persons suspected of criminal offenses, and privacy rights. Passions faded as the Warren and Burger Courts evolved into the Rehnquist and Roberts Courts. Prominent liberal commentators urged judicial minimalism, ${ }^{1}$ constitutional dialogues, ${ }^{2}$ deference to constitutional decisions made by elected officials, ${ }^{3}$ vesting ultimate constitutional authority in "the people themselves,"4 and "taking the Constitution away from the courts" entirely. ${ }^{5}$ Romance is blooming anew in the wake of Justice Antonin Scalia's death, illustrated by recent judicial decisions sustaining affirmative action ${ }^{6}$ and protecting abortion rights, ${ }^{7}$ and by the probability that only Democrats will have the opportunity to appoint Supreme Court justices for the foreseeable future. Mark Tushnet, a prominent sceptic of judicial power, now calls on young progressives in the legal academy to propose theories of liberal judicial activism, abandoning their previous "defensive crouch."

Progressive hopes for a joyous reunion with an activist judiciary are

* Mark Graber is the Regents Professor at the University of Maryland Francis King Carey School of Law. He earned his JD from Columbia and his $\mathrm{PhD}$ in political science from Yale and is recognized as one of the leading scholars in the country on constitutional law and politics. He is the author of $A$ New Introduction to American Constitutionalism from Oxford University Press and co-editor (with Keith Whittington and Howard Gillman) of American Constitutionalism: Structures and Powers and American Constitutionalism: Rights and Powers, both also from Oxford University Press. This Article is a revised version of the presentation Professor Graber gave during the Indiana Law Review Symposium held on November 6, 2015 entitled Partisan Conflict, Political Structure, and Culture.

1. See generally Cass R. Sunstein, One Case at a Time: Judicial Minimalism on the SuPREME COURT (1999).

2. See generally Louis Fisher, Constitutional Dialogues: Interpretation as Political Process (1988); Barry Friedman, Dialogue and Judicial Review, 91 Mich. L. Rev. 577 (1993).

3. See generally Ruth Colker \& James J. Brudney, Dissing Congress, 100 Mich. L. ReV. 80 (2001); Robert C. Post \& Reva B. Siegel, Protecting the Constitution from the People: Juricentric Restrictions on Section Five Power, 78 IND. L.J. 1 (2003).

4. See generally Larry D. Kramer, The People Themselves: Popular CONSTITUTIONALISM AND JUdiCIAL REVIEW (2004).

5. See generally Mark Tushnet, TAking the Constitution Away from the Courts (1999).

6. See Fisher v. Univ. of Tex. at Austin, 136 S. Ct. 2198, 2214-15 (2016).

7. See Whole Woman's Health v. Hellerstedt, 136 S. Ct. 2292, 2320 (2016).

8. See Mark Tushnet, Abandoning Defensive Crouch Liberal Constitutionalism, BALKINIZATION (May 6, 2016, 1:15 PM), http://balkin.blogspot.com/2016/05/abandoningdefensive-crouch-liberal.html [https://perma.cc/JQ6E-KZSB]. 
misplaced. The liberal judicial activism of June $2016^{9}$ has different political foundations than the liberal judicial activism of the Warren and Burger Courts. ${ }^{10}$ The liberal judicial activism of the third quarter of the twentieth century was generated by a political system structured by competition between two nonideological parties. ${ }^{11}$ The elite wings of both the Democratic and Republican Parties controlled the Justice Department in this time period and both were liberal on most civil rights issues. ${ }^{12}$ Democratic and Republican presidents made selfconscious efforts to appoint liberals to the court. ${ }^{13}$ The Republicans and Democrats they placed on the bench as a whole had similar liberal voting patterns. ${ }^{14}$ The result of these constitutional politics was bipartisan liberal judicial activism. ${ }^{15}$ The liberal judicial activism of June 2016, on the other hand, is generated by a political system structured by relative equal competition between two ideological parties. ${ }^{16}$ The elite wings of the Democratic and Republican Parties who take turns controlling the Justice Department are even more polarized than the general population. ${ }^{17}$ Democrats appoint judicial liberals to the federal courts. ${ }^{18}$ Republicans appoint judicial conservatives. ${ }^{19}$ With rare exceptions, Democratic judicial appointees take more liberal positions on all constitutional issues than Republican judicial appointments. ${ }^{20}$ The result of this constitutional politics is a judiciary badly divided between liberal and conservative blocs, with decisions depending on the fortuitous timing of judicial vacancies and the idiosyncrasies of the one quirky judge who was appointed during the time when the political system was transitioning from non-ideological to ideological parties. ${ }^{21}$

9. See, e.g., Obergefell v. Hodges, 135 S. Ct. 2584 (2015).

10. The argument in this paragraph is more fully developed in Mark A. Graber, Belling the Partisan Cats: Preliminary Thoughts on Identifying and Mending a Dysfunctional Constitutional Order, 94 B.U. L. ReV. 611 (2014) [hereinafter Graber, Belling the Partisan Cats]; and Mark A. Graber, The Coming Constitutional Yo-Yo? Elite Opinion, Polarization, and the Direction of Judicial Decision Making, 56How.L.J.661 (2013) [hereinafter Graber, The Coming Constitutional Yo-Yo]; see also infra Part III and accompanying text.

While the introduction has emphasized the Supreme Court's liberal turn in 2016, the argument applies equally to such contemporary instances of conservative judicial activism as Shelby County v. Holder, 133 S. Ct. 2612 (2013); Citizens United v. FEC, 558 U.S. 310 (2010); and District of Columbia v. Heller, 554 U.S. 570 (2008).

11. See infra Part II.

12. See id.

13. See id.

14. See id.

15. See id.

16. See infra Part III.

17. See id.

18. See id.

19. See id.

20. See id.

21. See id. 
Ideological parties, elite polarization, divided government, and electoral instability unmoor the course of judicial decision making from the structure of partisan competition. ${ }^{22}$ Ideological parties and elite polarization fuel efforts to secure partisan control of the courts. ${ }^{23}$ Electoral instability and divided government prevent either party from claiming a durable mandate to make their constitutional vision the law of the land.$^{24}$ In this political universe, neither party can contain a stable judicial majority, but each party controls the veto points necessary to prevent the other coalition from challenging any favorable decisions that happen to be made by the Supreme Court. ${ }^{25}$ Governing officials who once empowered courts to resolve certain constitutional issues are now politically disempowered from challenging particular liberal or conservative judicial decisions. ${ }^{26}$ Random events determine the course of Supreme Court decision making. The Supreme Court moved to the left in 2016 only because Justice Scalia happened to die before Justice Ginsburg and elected officials were too divided to either buttress the new judicial trend by confirming Judge Merrick Garland's nomination to the Court or to change the course of judicial decisions through hostile legislation. ${ }^{27}$ The result is an ideologically erratic course of judicial rulings on constitutional cases that is neither explained by any version of grand constitution or regime theory, ${ }^{28}$ nor justified by the connections to the rest of the political system necessary to support the judicial power having the final say on the meaning of constitutional provisions.

The following pages detail the changing connections between courts and the rest of constitutional politics that explain and justify judicial supremacy; how the combination of ideological parties, polarized elites, divided government, and electoral instability disconnect courts from the rest of the political system; and why, contrary to much inherited wisdom, the resulting judicial independence weakens the case for judicial supremacy in contemporary constitutional politics. ${ }^{29}$ The analysis integrates empirical explanations for judicial decisions with normative justifications for judicial decisions by highlighting the empirical presuppositions of grand constitutional theory and the normative ambitions of regime theory. ${ }^{30}$ Normative work justifies the practice of judicial supremacy in the United States, various works explicitly or implicitly acknowledge, only when

22. See id.

23. See id.

24. See id.

25. See id.

26. For an important discussion of the distinction between legislative deferrals and legislative defaults, see Scott E. Lemieux \& George Lovell, Legislative Defaults: Interbranch Power Sharing and Abortion Politics, 42 Polity 210, 215-16 (2010).

27. See Ariane de Vogue, Remember Merrick Garland? Supreme Court Nominee Waits (and Waits), CNN (Sept. 6, 2016), http://www.cnn.com/2016/09/06/politics/merrick-garland-supremecourt-wait/ [https://perma.cc/A2ZD-KS8D]; see also infra Part III.

28. See infra Part I.

29. See infra Parts I-IV.

30. See id. 
theory correctly describes practice. ${ }^{31}$ As Karl Llewellyn observed, "[T]here is no reaching a judgment as to whether any specific part of present law does what it ought, until you can first answer what it is doing now." ${ }^{32}$ That judicial review is justified whenever manna falls from heaven after the justices declare a law unconstitutional is beside the point because manna never falls from heaven after justices in the United States declare a law unconstitutional.

Part I discusses grand constitutional theory and regime theory, the most common justifications of and explanations for judicial power. ${ }^{33}$ Both offer normative assessments of judicial decision making, although the grand constitutional theory does so more explicitly. ${ }^{34}$ Both elaborate on the connections between courts and the structure of partisan competition that explain the course of judicial decision making, although regime theory does so more explicitly. ${ }^{35}$ Neither recognize that the structure of partisan competition in the United States changes over time. ${ }^{36}$ Neither explore how the combination of ideological parties, polarized elites, divided government and electoral instability, by undermining the empirical foundations for judicial supremacy, undermine common normative justifications for judicial supremacy. ${ }^{37}$

Part II discusses how the entrenchment of judicial supremacy that began at the turn of the twentieth century was intertwined with the long state of courts and parties $^{38}$ that structured American politics from the late nineteenth century until the late twentieth century. ${ }^{39}$ In this political order, courts made the constitutional rules and non-ideological parties distributed goods to various interests. ${ }^{40}$ Conservative proponents of the freedom of contract and liberal proponents of

31. See id.

32. Karl N. Llewellyn, Some Realism About Realism —Responding to Dean Pound, 44 HARV. L. REV. 1222, 1223 (1931).

33. See infra Part I.

34. See id.

35. See id.

36. Existing commentary comprehends the changes that occur within a structure of partisan competition. See generally Mark A. Graber, Separation of Powers, in THE CAMBRIDGE COMPANION to the United States Constitution (Karen Orren \& John Compton, eds.) (forthcoming). Both empirical and normative works seek to explain and justify the "Constitutional Revolution of 1937," which occurred after Democrats replaced Republicans as the dominant national coalition. See generallyid. That event, however, did not change the basic structure of "the long state of courts and politics." See generally id. Existing commentary does not discuss more structural changes, such as the shift from the ideological parties of the mid-nineteenth century to the non-ideological parties of the early twentieth century.

37. See infra Part I.

38. For the "long state of courts and parties," see Graber, Belling the Partisan Cats, supra note 10, at 637. On the "state of courts and parties," see StePhen SKowroneK, BuILDing A New American State: The Expansion of National Administrative Capacities 1877-1920, at 39 (1982).

39. See infra Part II.

40. See id. 
desegregated public schools agreed on this division of labor, although they disputed whether the regulation of the national economy raised questions of constitutional principle entrusted to courts or concerns with balancing interests entrusted to elected officials. ${ }^{41}$ Judicial power was connected to the rest of the constitutional order because both Democrats and Republicans in power staffed courts with elites who shared a bipartisan consensus on the most important constitutional issues of the times, even as crucial elements of that elite consensus were transformed during the New Deal. ${ }^{42}$ Judicial decisions from the 1890 s until the early 1970s had strong political foundations because they were consequences of consistent, self-conscious, and public efforts by a stable group of elected officials or governing officials removable at will by elected officials to foist particular issues on to the federal courts and to staff those federal courts with justices who shared a common perspective on those issues. ${ }^{43}$

Part III explains how the political foundations for judicial supremacy collapsed during the contemporary state of ideological parties, polarized elites, divided government, and electoral instability. ${ }^{44}$ The Supreme Court is no longer staffed by justices who, because they were appointed by a relatively enduring dominant national coalition or bipartisan elites, share a common constitutional vision generated by the underlying political system. ${ }^{45}$ Ideological parties fueled by polarized elites strive to make their distinctive constitutional visions the official law of the land. ${ }^{46}$ Electoral stability and divided government prevent any faction that shares a constitutional vision from establishing secure control over the federal judiciary or gaining the power necessary to interfere with a contrary course of judicial decision making. ${ }^{47}$ That course of judicial decision making turns on accidents of retirements, deaths, and appointments, as well as the peculiarities of "stealth" justices. ${ }^{48}$ Roberts Court liberalism was triggered by the death of Justice Antonin Scalia rather than any change within the structure of partisan competition that moved constitutional politics as a whole leftward. ${ }^{49}$ Such judicial decisions as Whole Woman's Health v. Hellerstedt,$^{50}$ Fisher $v$. University of Texas at Austin, ${ }^{51}$ and Obergefell v. Hodges ${ }^{52}$ lack political foundations because, in contrast to Brown v. Board of Education, ${ }^{53}$ New York

41. See id.

42. See id.

43. See id.

44. See infra Part III.

45. See id.

46. See id.

47. See id.

48. See id.

49. See id.

50. 136 S. Ct. $2292(2016)$.

51. 136 S. Ct. 2198 (2016).

52. 135 S. Ct. 2584 (2015).

53. 347 U.S. 483 (1954). 
Times Co. v. Sullivan, ${ }^{54}$ and Reynolds v. Sims,${ }^{55}$ they are not products of the consistent, self-conscious, and relatively public decisions by a stable group of elected officials or governing officials removable at will by elected officials to foist certain issues on the judiciary and staff the judiciary with justices who share a common perspective on those issues. ${ }^{56}$

Part IV maintains that the allocation of constitutional authority in the United States or in any constitutional democracy should be determined in light of how partisan competition is structured at that time and place. ${ }^{57}$ Judicial supremacy is and should be politically constructed. ${ }^{58}$ The judicial capacity to have the final say on the meaning of constitutional provisions is and should be grounded in choices made by elected officials or governing officials who may be removed at will by elected officials. ${ }^{59}$ Warren Court legal liberalism had legitimate political foundations.$^{60}$ During the mid-twentieth century, liberals in the executive and legislative branches of the national government empowered courts to decide certain constitutional issues in ways that connected the course of judicial decision making to the structure of the partisan competition of the times. ${ }^{61}$ Attacks on such judicial rulings as Brown v. Board of Education were attacks on how the Roosevelt, Truman, and Eisenhower administrations, assisted by their allies in Congress, as they often appeared, claims that courts were eroding the capacity of elected officials to govern. ${ }^{62}$ Roberts Court legal liberalism lacks those legitimate political foundations. ${ }^{63}$ The structure of partisan competition at present disconnects the course of judicial decision making from the structure of partisan politics by preventing both liberal Democrats and conservative Republicans from influencing the composition of the Supreme Court or the rulings issued by the surviving justices. ${ }^{64}$ Attacks on such decisions as Fisher and Whole Woman's Health amount to attacks on a justice whose degree of commitment to conservative constitutional visions was not fully ascertained when he was

54. 376 U.S. 254 (1964).

55. 377 U.S. 533 (1964).

56. See infra Part III.

57. See infra Part IV.

58. See generally Keith E. Whittington, Political Foundations of Judicial Supremacy: The Presidency, the Supreme Court, and Constitutional Leadership in U.S. History (2007); see also Mark A. Graber, Constructing Judicial Review, 8 AnN. Rev. POL. SCI. 425, 446 (2005).

59. See infra Part IV.

60. See id.

61. See generally Kevin J. McMahon, Reconsidering Roosevelt on Race: How the Presidency Paved the Road to Brown (2004); Lucas A. Powe, Jr., The Warren Court and American Politics (2000); Howard Gillman, Party Politics and Constitutional Change: The Political Origins of Liberal Judicial Activism, in The Supreme Court And Constitutional Change (Ronald Kahn \& Ken I. Kersch eds., 2006).

62. See infra Part IV.

63. See id.

64. See id. 
appointed to the Supreme Court, and not criticism of a steady course of decisions made by members of a dominant political coalition or a bipartisan elite. ${ }^{65}$ No good reason exists for any justice or constitutional decision maker to treat as binding precedent decisions that are the fortuitous outcome of the timing of judicial vacancies and the idiosyncrasies of one or two justices. ${ }^{66} \mathrm{Judicial}$ supremacy does not require judicial independence because popular constitutionalism is not the alternative to judicial supremacy. The "people themselves" have the same power to choose whether to vest the Supreme Court of the United States with the power to determine the constitutional status of samesex marriage as they have to decide whether persons have a constitutional right to same-sex marriage. ${ }^{67}$ To the extent a course of judicial decisions is rooted in consistent, self-conscious, and relatively public choices made by elected officials of governing officials who may be removed at will by elected officials, the argument for giving final say to the Supreme Court combines the strength of the traditional arguments for judicial supremacy (courts have special virtues) ${ }^{68}$ with the arguments for popular constitutionalism (the people have endorsed some version of the argument for judicial supremacy) ${ }^{69}$ The legal liberalism of the Warren Court was legitimate because that course of judicial decision making had those strong political foundations. ${ }^{70}$ That the Supreme Court in 2016 is arguably more independent from the elected branches of the national government than at any previous point in the history of the United States weakens, rather than strengthens, the case for treating the justices as having the final say on constitutional controversies over abortion, affirmative action, and any other matter decided during the 2015-2016 judicial term. ${ }^{71}$

\section{EXPLAINING AND JUSTIFYING JUDICIAL SUPREMACY}

Constitutional commentators rely on two different models when considering the relationship between courts and the rest of the political system. The best known model has been labelled "grand theory" 72 or "grand constitutional theory." Most grand constitutional theorists assume that judicial decisions declaring laws unconstitutional challenge policies adopted by elected officials. ${ }^{74}$

65. See id.

66. See id.

67. See id.

68. See generally Frederick Schauer, Judicial Supremacy and the Modest Constitution, 92

Cal. L. Rev. 1045 (2004).

69. See generally KRAMER, supra note 4.

70. See infra Part IV.

71. See id.

72. Mark Tushnet, Red, White, and Blue: A Critical Analysis of Constitutional LAW 1-4 (2015).

73. See generally Keith E. Whittington, Herbert Wechsler's Complaint and the Revival of Grand Constitutional Theory, 34 U. Rich. L. REV. 509 (2000).

74. See, e.g., Alexander M. Bickel, The Least Dangerous Branch: The Supreme Court at the Bar of Politics 16-17 (1962). 
"[W]hen the Supreme Court declares unconstitutional a legislative act or the action of an elected executive," Alexander Bickel famously declared, "it thwarts the will of representatives of the actual people of the here and now; it exercises control, not in behalf of the prevailing majority, but against it." 75 The other model is conventionally known as regime theory. Regime theorists insist that judicial review is politically constructed, that judicial review exists because crucial political actors believe their interests and policy goals will best be served by giving the Supreme Court the final say on what the constitution means. "Whenever the Supreme Court declare[s] a policy unconstitutional," regime theorists think, "key actors in the dominant national coalition typically either facilitate[] or otherwise bless[] [the] judicial ruling[]."

Devotees of grand constitutional regime theory acknowledge that judicial authority has and should have political foundations. ${ }^{77}$ Grand constitutional theorists elaborate justifications for judicial supremacy, but their works also consider why courts declare laws unconstitutional. Bickel and others believe that judicial power is empirically grounded by American commitments to ensuring that some issues are decided on constitutional principle rather than by majoritarian interest. ${ }^{78}$ Regime theorists explain judicial power, but their model also provides foundations for justifying judicial supremacy. ${ }^{79}$ Terri Perreti and others suggest that judicial review is justified when courts are carrying out missions assigned to them by members of the dominant national majority or by a stable group of political actors who control institutions that give them disproportionate influence over the staffing of the Supreme Court. ${ }^{80}$

Both grand constitutional theory and regime theory understand that judicial supremacy is a political choice. ${ }^{81}$ Popular sentiment and political actors must empower the Court to declare laws unconstitutional. Judicial supremacy exists because Americans recognize the judicial power to have the final say over the meaning of constitutional provisions as an essential element of constitutional democracy or because crucial political actors with relatively stable control over the staffing of the federal judiciary think a particular course of judicial decisions will advance their values and interests. Grand constitutional theorists claim Americans want courts to act on the basis of constitutional principle. ${ }^{82}$ Regime theorists claim to explain why justices act on the basis of some constitutional

75. Id.

76. Mark A. Graber, The Nonmajoritarian Difficulty: Legislative Deference to the Judiciary, 7 Stud. Am. Pol. Dev. 35, 71 (1993).

77. See, e.g., BICKEL, supra note 74, at 20.

78. Id.

79. See generally Terri Jennings Peretti, In Defense of a Political Court (1999); Howard Gillman, Regime Politics, Jurisprudential Regimes, and Unenumerated Rights, 9 U. PA. J. CONST. L. 107 (2006).

80. See Peretti, supra note 79; Gillman, supra note 79, at 118.

81. See, e.g., BICKEL, supra note 74; Gillman, supra note 79.

82. See, e.g., BICKEL, supra note 74 , at 13-17. 
principles and not others. ${ }^{83}$ Neither grand constitutional theory nor regime theory is particularly useful for thinking about a course of judicial decision making that neither reflects any coherent set of constitutional principles nor serves the interests of an identifiable and stable group of political actors.

Grand constitutional and regime theory both fail to account for erratic courses of judicial decision making because each is rooted in claims about the structure of political competition in the United States that better describe constitutional politics in 1916 and $1966,{ }^{84}$ when the Supreme Court was embarked on a fairly consistent course of decision making, than in 2016, when the course of judicial decision making is far more ideologically erratic. Grand constitutional theorists who describe American legislative and electoral politics as a struggle between non-ideological parties who seek to balance various interest groups capture crucial dimensions of the long state of courts and parties, but do not do justice to the present state of ideological parties. Regime theory's efforts to describe stable alliances between Supreme Court justices and members of the dominant national coalition capture the bipartisan elite that exercised disproportionate influence over the federal judiciary during the twentieth century, but do not do justice to the more complicated relationships between the justices and the polarized elites of the twenty-first century. By implicitly treating the structure of constitutional politics at the time of the Warren Court as a constant rather than as a variable, neither the grand constitutional nor regime theory identify or analyze the contemporary political foundations of judicial power.

\section{A. Justifying Judicial Supremacy: Grand Constitutional Theory and the Countermajoritarian Difficulty}

Grand constitutional theory begins with a countermajoritarian difficulty ${ }^{85}$ that disconnects courts from the rest of the political system. As noted above, most normative justifications of judiciary supremacy start by acknowledging that exercises of the judicial power to declare laws unconstitutional "thwart the will" of governing majorities. ${ }^{86}$ Justices reach different conclusions on the heated constitutional controversies of the day, grand constitutional theory maintains, because justices use a different decisional calculus than elected officials ${ }^{87}$ Elected officials make utilitarian decisions that balance the concerns of their constituents or various interest groups. ${ }^{88}$ Justices make or are supposed to make decisions on constitutional principle that are indifferent to the particular individuals or groups benefitted or burdened. ${ }^{89}$ While "principles are largely instrumental as they are

83. See, e.g., Graber, supra note 76 , at 71.

84. Or, for that matter, 1866. See Graber, supra note 36.

85. See Barry Friedman, The History of the Countermajoritarian Difficulty, Part One: The Road to Judicial Supremacy, 73 N.Y.U. L. REV. 333, 334-35 (1998).

86. BICKEL, supra note 74 , at 16-17.

87. See id. at 16-33.

88. See id. at 24-33.

89. Herbert Wechsler, Toward Neutral Principles of Constitutional Law, 73 HARV. L. Rev. 1, 14-15 (1959). 
employed in politics," Herbert Wechsler's influential Toward Neutral Principles of Constitutional Law maintained, "The main constituent of the judicial process is precisely that it must be genuinely principled, resting with respect to every step that is involved in reaching judgment on analysis and reasons quite transcending the immediate result that is achieved." $" 90$

When constitutional politics is functioning properly, grand constitutional theorists claim the constitutional order in the United States generates a federal bench composed of justices who are independent in all ways from their original political sponsors. ${ }^{91}$ Life tenure severs connections between federal courts and the rest of the political system by freeing justices from the need to appease elected officials or their constituents. Christopher Eisgruber contends, "Life tenure enhances the possibility that judges will approach moral issues in a disinterested fashion, and so bring to bear upon those issues the right kinds of reasons-reasons that flow from a genuine effort to distinguish between right and wrong, rather than from self-interest." ${ }^{92}$ Life tenure also enables justices to enhance their capacity to make decisions on constitutional principle. Bickel declared, "Judges have, or should have, the leisure, the training, and the insulation to follow the ways of the scholar in pursuing the ends of government." 93

Proponents of judicial supremacy nevertheless detect crucial links between the judicial mission to decide on constitutional principle and the rest of the political system that both explain and justify judicial supremacy. In their view, the judicial power to declare laws unconstitutional does not raise a countermajoritarian problem, even if every particular exercise of the judicial power to declare laws unconstitutional does, because the judicial mission to decide on constitutional principle has popular and political foundations. Americans recognize that a purely interest-driven politics is not desirable. Bickel described this as

a premise we deduce not merely from the fact of a written constitution but from the history of the race, and ultimately as a moral judgment of the good society, that government should serve not only what we conceive from time to time to be our immediate material needs but also certain enduring values. ${ }^{94}$

90. Id. See BiCKeL, supra note 74, at 27; Henry M. Hart, Jr., Foreword: The Time Chart of the Justices, 73 HARV. L. REV. 84, 99 (1959). Bruce Ackerman proposes an important variation on this theme. In his view, electoral politics is about constitutional principles during short periods he describes as "constitutional regimes." See Bruce AcKerman, We the PeOPle: Foundations 5867 (1991). After those moments end, politics reverts to interest bargaining, leaving courts with the responsibility of making decisions on the constitutional principles adopted during previous constitutional moments. See id.

91. See Christopher L. Eisgruber, Constitutional Self-Government 46-78 (2001).

92. Id. at 78 .

93. BICKEL, supra note 74 , at 25-26.

94. Id. at 24 . 
Americans and American governing officials self-consciously balance interest and principle by structuring the political universe so that some governing institutions are attentive to the interest dimensions of politics and others are attentive to the principled or constitutional dimensions of politics. The political scientist Robert McCloskey elaborated on the model of politics underlying the grand constitutional theory of his time when he observed:

For with their political hearts thus divided between the will of the people and the rule of law, Americans were naturally receptive to the development of institutions that reflected each of these values separately. The legislature with its power to initiate programs and policies, to respond to the expressed interest of the public, embodied the doctrine of popular sovereignty. The courts, generally supposed to be without will as Hamilton said, generally revered as impartial and independent, fell heir almost by default to the guardianship of the fundamental law. It did not avail for Jeffersonian enemies of the judicial power to insist that a single department could exercise both the willing and the limiting functions. The bifurcation of the two values in the American mind impellingly suggested that the functions should be similarly separated. And the devotion of Americans to both popular sovereignty and fundamental law insured public support for the institution that represented each of them. ${ }^{95}$

This model retains its hold over more contemporary thinkers. Eisgruber maintains that justices are as representative as elected officials. ${ }^{96}$ The Supreme Court, in his view, merely represents a different dimension of the American people. ${ }^{97} \mathrm{He}$ concludes judicial review is consistent with democracy because "The people need an institution likely to reflect their judgments about justice, rather than their interests." 98

These constitutional politics justify vesting the Supreme Court with the final say over the meaning of most constitutional provisions. ${ }^{99}$ Judicial review is politically constructed because Americans as a whole and American elected officials recognize that courts make some decisions better than legislators or members of the executive branch. Courts, Henry M. Hart, Jr. declared, are "charged with the creative function of discerning afresh and of articulating and developing impersonal and durable principles." ${ }^{100}$ Grand constitutional theorists are often unclear on the precise mechanism by which Americans give this charge to the Court. Nevertheless, that Americans implicitly or explicitly charge the

95. Robert G. McCloskey, The American Supreme Court 7-8 (5th ed. 2010).

96. EISGRUBER, supra note 91 , at 78.

97. Id.

98. Id.

99. The political questions doctrine acknowledged that elected officials had the final say over the few constitutional provisions that were best interpreted by the President and members of Congress. See generally Baker v. Carr, 369 U.S. 186 (1962).

100. Hart, supra note 90, at 99 (emphasis added). 
Court explains and justifies judicial supremacy. Judicial supremacy follows from the claim that Americans are entitled to act on their belief that courts are better than elected officials at resolving certain constitutional controversies. Much debate exists over the best division of labor between courts and other officials. Some commentators insist that justices provide better protections for fundamental rights, ${ }^{101}$ while others maintain that courts are better suited to protect the democratic process. ${ }^{102}$ Originalists insist that judges are better than elected officials at detecting the original meaning of constitutional provisions. ${ }^{103}$ What unites these responses to the countermajoritarian difficulty is the common understanding that Americans recognize that courts perform some functions better than any other governing institution.

Grand constitutional theorists conclude that democratic opposition to judicial review is based on a category mistake. The countermajoritarian difficulty contrasts judicial review and democracy because each particular decision the justices make is opposed by governing majorities. Governing majorities, nevertheless, favor the practice of judicial review, and democratic principles allow governing majorities to choose the institution responsible for settling constitutional controversies. Even Tushnet, who champions a populist constitutionalism that eschews judicial review, ${ }^{104}$ admits that the proposal to abandon the judicial power to declare laws unconstitutional is countermajoritarian because the public wants judicial review, even as their will is thwarted on particular policies more often than not. ${ }^{105}$ "Different people disagree about when the courts abuse power," he observes, "but we seem to think that an institution pretty much like the one we have is good for us."106 Tushnet continues, "Arguments against judicial review are in this sense anti-populist, for they try to argue that we should not want what we actually do want." 107

\section{B. Explaining Judicial Supremacy Regime Theory}

Abraham Lincoln is the founder of regime theory. During his fifth debate with Stephen Douglas, Lincoln connected judicial decisions protecting slavery with the then-dominant Jacksonian coalition. ${ }^{108} \mathrm{He}$ asserted,

[T]he Dred Scott decision, as it is, never would have been made in its

101. See generally Michael J. Perry, The Constitution, The Courts, and Human Rights (1982).

102. See generally John Hart Ely, Democracy and Distrust: A Theory of Judicial REVIEW (1980).

103. See generally Keith E. Whittington, Constitutional Interpretation: Textual MEANing, ORIGinal InTENT, AND Judicial REVIEW (1999).

104. Tushnet, supra note 8, at 154-76.

105. Id.

106. Id. at 173 .

107. $I d$.

108. 3 Abraham Lincoln, The Collected Works of Abraham Lincoln 207-44 (Roy P. Basler ed., 1953). 
present form if the party that made it had not been sustained previously by the elections. My own opinion is, that the new Dred Scott decision, deciding against the right of the people of the States to exclude slavery, will never be made, if that party is not sustained by the elections. I believe, further, that it is just as sure to be made as to-morrow is to come, if that party shall be sustained. ${ }^{109}$

The future sixteenth President of the United States regarded Dred Scott as the result of a conspiracy between the present Jacksonian President of the United States, the most recent Jacksonian President of the United States, the leader of the Jacksonian forces in the Senate, and the Jacksonian Chief Justice of the United States, rather than as an instance when unelected federal judges thwarted the will of the representatives of the people of the here and now. ${ }^{110}$ Lincoln informed listeners in Ottawa, Illinois, "we fell [sic] it impossible not to believe that Stephen [Douglas] and Franklin [Pierce], and Roger [Taney] and James [Buchanan], all understood one another from the beginning, and all worked on a common plan or draft drawn before the first blow was struck." 111

Lincoln anticipated the central themes of regime theory when elaborating on Taney Court decision making. A Jacksonian conspiracy explained Dred Scott, but was not a normative justification for deferring to judicial wisdom on the constitutional status of slavery. Unlike grand constitutional theorists, Lincoln was concerned with the political foundations for a particular course of judicial decision making. ${ }^{12}$ Dred Scott was the product of an alliance between Jacksonians in all branches of the national government who were attempting to fashion a constitutional commitment to national protection for slavery. ${ }^{113}$ This alliance explained why the Taney Court forbade Congress from banning slavery in the territories, but not why the Marshall Court permitted Congress to incorporate a national bank. ${ }^{114}$ Jacksonians, Lincoln pointed out, had no generalized commitment to judicial power when their coalition did not control the Supreme Court. ${ }^{115}$

Lincoln was a normative theorist in addition to being an empirical analyst. When explaining the course of judicial decision making during the $1850 \mathrm{~s}$, the

109. Id. at 232 .

110. Id. at 20. Republicans did think that Dred Scott was a product of an undemocratic Slave Power. See generally Mark A. Graber, Constructing Constitutional Politics: The Reconstruction Strategy for Protecting Rights (2013) (unpublished manuscript) (on file with Yale Law School). The democratic problem with American politics in their view, however, concerned the institutional mechanisms that enabled a southern minority to control the elected branches of the national government. See id. No Republican claimed that Dred Scott was even less democratic than the rest of the political system. See id.

111. 3 LiNCOLN, supra note 108 , at 20.

112. Id.

113. Id.

114. See McCulloch v. Maryland, 17 U.S. 316, 436-37 (1819).

115. See 2 Lincoln, supra note 108, at 402-03 (noting vigorous Jacksonian opposition to judicial decisions sustaining the national bank). 
Illinois Republican set out the political foundations that he believed would justify Dred Scott and related pro-slavery decisions. ${ }^{116}$ His speeches claimed that a consistent, self-conscious, and relatively public concurrence between a stable group of elected officials and justices vested the Supreme Court with final authority over the meaning of constitutional provisions. ${ }^{117}$ " $[\mathrm{I}] \mathrm{t}$. . . would be, factious, nay, even revolutionary, to not acquiesce . . . as a precedent," Lincoln declared, any judicial decision consistent "with the steady practice of the departments throughout our history ... [that] had been before the court more than once, and had there been affirmed and re-affirmed through a course of years."118 Lincoln's goal in 1858 and 1860 was to prevent such an enduring concurrence on the constitutional right to bring slaves in American territories from occurring.

Following Lincoln, contemporary regime theorists drew tight connections between the political system and the federal judiciary. Robert Dahl declared, "It would appear, on political grounds, somewhat unrealistic to suppose that a Court whose members are recruited in the fashion of Supreme Court Justices would long hold to norms of Right or Justice substantially at odds with the rest of the political elite." ${ }^{119}$ Powerful factions outside of the judiciary ally with federal judges to determine the course of judicial decision making. Charles Fairman declared, "[T] he historian of the Court should keep his watch in the halls of Congress." 120 Keith Whittington details how "Presidents . . . have been particularly important in determining the relative authority of the Supreme Court to say what the Constitution means." ${ }^{121}$ Finley Peter Dunne's Mr. Dooley put the point most succulently when he declared, "[T]h' supreme coort follows th' iliction returns." $" 122$

Regime theorists follow Lincoln in their concern with particular courses of judicial decisions. Judicial authority survives, Dahl and others believe, because all particular courses of judicial decision making have political foundations, even as those political foundations change over time. ${ }^{123}$ What matters is that a stable group of crucial political actors at time A provide support for the particular course of judicial decision making at time A, not whether those political actors provided or would have provided the same political support for any course of judicial decisions at time A or for all courses of judicial decisions throughout American history. Regime theorists think changes in the political foundations of judicial review explain changes in the course of judicial decision making. ${ }^{124}$ The

116. Id. at 403-06.

117. See 2 LinCOLN, supra note 108; 3 LinCOLN, supra note 108.

118. 2 LinCOLN, supra note 108 , at 401.

119. Robert A. Dahl, Decision-Making in a Democracy: The Supreme Court as a National Policy-Maker, 50 EMORY L.J. 563, 578 (2001).

120. 6 Charles Fairman, History of the Supreme Court of the United States: RECONSTRUCtion AND REUnion, 1864-88, at 118 (1971).

121. WhitTington, supra note 58, at 5.

122. Mr. DoOley's Opinions 26 (1901).

123. See Dahl, supra note 119.

124. See id. at 570-77. 
Supreme Court became more liberal after the New Deal because the conservatives who provided the political foundations for Supreme Court decision making before 1933 were replaced by the liberals who provided the political foundations for Supreme Court decision making after $1937 .{ }^{125}$ Martin Shapiro points to the various ways that New Dealers sought to "transfer [the Supreme Court's] patronage from a Republican to a Democratic clientele."126

Governing officials have two reasons for facilitating particular courses of judicial decision making. Crucial political elites often champion the same constitutional vision that animates the judicial majority. The Roosevelt, Truman, and Eisenhower Justice Departments aggressively pushed to have the Supreme Court strike down Jim Crow practices. ${ }^{127}$ Republicans at the turn of the twentyfirst century as aggressively sought to fashion a Supreme Court more sympathetic to federalism. ${ }^{128}$ Crucial political actors sometimes favor having the courts take the lead in resolving certain hot-button issues, regardless of the decision the courts make. James Buchanan was far more interested in having the Court take responsibility for resolving the constitutional status of slavery in the territories than any particular resolution a Court largely staffed with Jacksonians might reach. ${ }^{129}$ John Hart Ely's attack on the Supreme Court's decision to protect abortion rights in Roe v. Wade noted, "The sighs of relief as this particular albatross was cut from the legislative and executive necks seems to be audible."130

Support for a particular course of judicial decisions does not entail support for every decision made by an allied Court. Martin Shapiro, Alex Sweet Stone, and Gordon Silverstein analogize judicial review to a junkyard dog. ${ }^{131}$ They assert,

If you own a junkyard . . . and want to protect it, you might release a vicious dog at night to patrol the premises. The dog ... will do a fine job of protecting you against others if it is mean enough and unwilling to take orders from anyone. But of course, if that's true, there is a real risk that this dog might take a nip out of its master. That may just be the price you have to pay to use this method of protection. ${ }^{132}$

125. Id.

126. Martin Shapiro, The Supreme Court: From Warren to Burger, in THE NEw AMERICAN Political System 179, 190-91 (Anthony King ed., 1978).

127. See generally Kevin J. McMahon, Nixon's Court: His Challenge to Judicial Liberalism AND Its Political ConseQuences (2011).

128. See generally J. Mitchell Pickerill \& Cornell W. Clayton, The Rehnquist Court and the Political Dynamics of Federalism, 2 PERSP. ON POL. 233 (2004).

129. See Graber, supra note 76, at 48-49.

130. John Hart Ely, The Wages of Crying Wolf: A Comment on Roe v. Wade, 82 YALE L.J. 920, 947 (1973).

131. See Gordon Silverstein, Sequencing the DNA of Comparative Constitutionalism: A Thought Experiment, 65 Md. L. Rev. 49, 50 (2006) (citing Martin Shapiro \& Alec Stone Sweet, On Law, Politics, And Judicialization 163-64 (2002)).

132. Id. 
Allied courts function similarly. On most matters, these courts act consistently with the constitutional vision of their political sponsors. At times the justices go rogue. Nevertheless, governing officials will provide political foundations for a course of judicial decision making as long as they believe judicial review advances their purposes more often than not and no plausible alternative exists that would better advance those purposes. ${ }^{133}$

No general agreement exists among regime theorists on which political actors provide the political foundations for judicial authority. Dahl suggested the political elite or the dominant national coalition. ${ }^{134}$ Lincoln discussed political parties. ${ }^{135}$ Fairman would have scholars focus on Congress. ${ }^{136}$ Whittington emphasizes the President. ${ }^{137} \mathrm{Mr}$. Dooley concentrates on election returns. ${ }^{138}$ Barry Friedman writes about how public opinion determines the course of Supreme Court decision making. ${ }^{139}$ This creates problems testing regime theory. Several recently published papers claim to refute regime theory by demonstrating that the courts do not consistently advance the constitutional preferences of any particular group of political actors. ${ }^{140}$

The best approach may be that different political actors provide different kinds of political foundations for different courses of judicial decision making at different times so that no grand theory exists that covers the universe of Supreme Court decisions other than that the vast majority have political foundations of some sort. Kevin McMahon details how the Nixon administration successfully influenced judicial decision making on constitutional criminal procedure but for the most part was uninterested in influencing the course of judicial decisions on the freedom of speech. ${ }^{141}$ The Justice Department from 1933 to 1954 provided the political foundations for the line of decisions leading to and following Brown v. Board of Education.$^{142}$ At the turn of the twentieth century, a bipartisan group of congressional leaders pushed questions about federal regulation of the national economy onto the Supreme Court. ${ }^{143}$ However, decisions on abortion rights, such as Roe v. Wade, ${ }^{144}$ are best conceptualized as instances when the political

133. See Silverstein, supra note 131, at 52-67.

134. See Dahl, supra note 119, at 569-81.

135. See 2 Lincoln, supra note 108; 3 LinColn, supra note 108.

136. See 6 FAIRMAN, supra note 120 , at 118 .

137. See Whittington, supra note 58 , at 5.

138. See Mr. Dooley's Opinions, supra note 122, at 26.

139. See generally Barry Friedman, The Will of the People: How Public Opinion Has Influenced the Supreme Court and Shaped the MeAning of the Constitution (2009).

140. See Matthew E. K. Hall, Rethinking Regime Politics, 37 L. \& Soc. INQUiRy 878, 878 (2012); Thomas M. Keck, Party, Policy or Duty: Why Does the Supreme Court Invalidate Federal Statutes, 101 Am. Pol. ScI. ReV. 321, 321-28 (2007).

141. See McMAHON, supra note 127.

142. See MCMAHON, supra note 61.

143. See generally George I. Lovell, Legislative Deferrals: Statutory Ambiguity, Judicial Power, AND American Democracy (2003).

144. 410 U.S. 113 (1973). 
foundations for a course of judicial decision making were established by passive legislative default than active legislative deferral. ${ }^{145}$ This diversity of the political foundations for different courses of judicial decisions at different times suggests that little will be gained by efforts to assess whether judicial decisions declaring school segregation unconstitutional in the third quarter of the twentieth century have the same political foundations as judicial decisions determining the rules for Article I courts at the turn of the twenty-first century. ${ }^{146}$

Regime theory was developed primarily to explain judicial review, but many regime theorists acknowledge that their empirical finding that judicial review is hardly ever countermajoritarian has normative bite. If, as grand constitutional theorists suggest, political support for courts justifies judicial supremacy, even though no such support exists for any particular decision, then political support for a particular course of judicial decisions justifies treating those decisions as authoritative. Even the political actors who laid the political foundations for the course of decision disagree with particular rulings. When discussing "the modern debate about the legitimacy of unenumerated rights," Howard Gillman observed that "the basic rubric ... is sufficiently popular among the public and governing elites that it will remain an ongoing feature of the Court's jurisprudence." ${ }^{147}$ The case may be made for giving the courts final authority for making a constitutional decision when the justices are the only actors willing to make that final decision. "[D]emocratic values are better promoted by having some conflicts resolved by justices appointed and confirmed by elected officials," the argument goes, "when the practical alternative is not having those conflicts resolved at all.",148

\section{The Structure of Constitutional Politics}

The constitutional universes underlying grand constitutional and regime theory are strikingly similar, despite obvious differences. Both explain and justify judicial supremacy as a consequence of actions by a stable group of governing officials who provide justices with a consistent, self-conscious, and relatively public mission. ${ }^{149}$ Both insist that the relevant inquiry is the political foundations for judicial missions rather than the political foundations for any particular

145. See Lemieux \& Lovell, supra note 26, at 216.

146. See, e.g., Stern v. Marshall, 564 U.S. 462 (2011).

147. Gillman, supra note 79, at 118. See generally PARETTI, supra note 79.

148. Graber, supra note 76 , at 73 . Some regime theorists question whether the political foundations for a course of judicial decision making provide normative foundations for that course of judicial decision making. See George I. Lovell \& Scott F. Lemieux, Assessing Juristocracy: Are Judges Rulers or Agents, 65 MD. L. REv. 100, 114 (2006) ("When legislators shift divisive social issues to the judicial branch because they want to avoid electoral accountability for making hard choices, their actions raise significant concerns about democratic accountability."). For a discussion of the potential coherence, polarization, accountability, and bias problems with politically constructed judicial review, see Mark A. Graber, The Countermajoritarian Difficulty: From Courts to Congress to Constitutional Order, 4 AnN. REV. L. Soc. ScI. 361, 380-81 (2008).

149. See supra Parts I.A \& I.B. 
judicial decision. ${ }^{150}$ Both agree that governing officials take an active role empowering the federal judiciary because ordinary politics is not capable of properly resolving those issues that come before the Supreme Court. ${ }^{151}$ Both point to stable features of American constitutional politics that enable government officials to provide justices with permanent or relatively enduring missions. ${ }^{152}$ Finally, both believe that these foundations for judiciary supremacy should generate a consistent course of judicial decision making. ${ }^{153}$

Grand constitutional and regime theory are concerned with the political foundations of judicial missions. Political officials empower justices to champion fundamental values, not make discrete decisions. The judicial power to have the final say on constitutional controversies is rooted in the political foundations of those missions rather than in any individual decision. Grand constitutional theory maintains that the justices have always been charged with deciding constitutional issues on the basis of constitutional principle. ${ }^{154}$ Judicial supremacy has legitimate political foundations to the extent judicial decisions are based on "neutral principles of constitutional law." $" 155$ Regime theory insists that different constitutional orders charge justices with different constitutional missions, missions that change over time in light of durable changes in the underlying constitutional politics. ${ }^{156}$ Judiciary supremacy has legitimate political foundations as long as the justices are carrying out a mission generated by the constitutional order, whether that mission be promoting free enterprise or guaranteeing racial equality.

Persons outside the judiciary take a proactive role in providing the political foundations that explain and justify judicial review. The classics of regime theory meticulously detail how various political elites set in motion a course of favorable judicial decisions. Howard Gillman documented how congressional Republicans in the late nineteenth century sponsored legislation expanding the federal judiciary and federal jurisdiction that provided the political foundations for the conservative Supreme Court activism at the turn of the twentieth century. ${ }^{157}$ George Lovell elaborated on how a bipartisan group of congressional leaders manipulated legislative language in ways that facilitated conservative Supreme Court decisions during the first decades of the twentieth century on national power over the economy and the rights of employees. ${ }^{158}$ Bruce Ackerman aside, ${ }^{159}$

150. See id.

151. See id.

152. See id.

153. See id.

154. See supra Part I.

155. Wechsler, supra note 89.

156. See supra Part I.B.

157. See generally How Political Parties Can Use the Courts to Advance Their Agendas: Federal Courts in the United States, 1875-1891, 96 Am. PoL. ScI. Rev. 511 (2002).

158. LOVELL, supra note 143.

159. Bruce Ackerman's works document at great detail the political steps political elites take during "constitutional moments" to ensure a particular course of favorable judicial decisions. See, 
grand constitutional theorists are more prone to assert than detail the political foundations for judicial review. Still, history offers clear political foundations for the judicial power that normative theory celebrates. Before the federal judiciary decided Marbury v. Madison (1803) ${ }^{160}$ Congress passed the Judiciary Act of 1789, which explicitly authorized the Supreme Court to declare laws unconstitutional. ${ }^{161}$ Had Congress never established a federal judicial system ${ }^{162}$ or if Congress had repealed the statutes that vested jurisdiction over state decisions in the federal courts, federal courts would not have existed or been empowered to declare laws unconstitutional. ${ }^{163}$

Governing officials throughout American history have needed to provide political foundations for judicial supremacy because the federal judiciary is the only institution capable of resolving certain constitutional controversies on constitutional principle. Grand constitutional theorists make this claim explicitly. ${ }^{164}$ Institutional structures, in their view, give elected officials and justices different motives. ${ }^{165}$ Elected officials who must engage in interest balancing in order to maintain their offices cannot be relied on to make principled constitutional judgments routinely made by justices with life tenure. ${ }^{166}$ Regime theory reaches a similar conclusion by examining how institutional structures influence legislative and judicial capacity. ${ }^{167}$ Most regime theorists think that political actors outside of courts act on constitutional principles all the time. ${ }^{168}$ The presidents Whittington studies have constitutional motivations, ${ }^{169}$ as did the members of the Reconstruction Congress analyzed by Fairman. ${ }^{170}$ The problem principled constitutionalists in the legislative and executive branches of government face is that either the elected branches of the government contain too many veto points or their party is not sufficiently united on constitutional principles to make their constitutional vision the official law of the land through legislation. The only possible winning strategy for many governing officials who are motivated by constitutional principle, but frustrated by electoral gridlock, is to create the political foundations necessary for a five or more justice majority prepared to act on their preferred constitutional principles. The point of

e.g., Bruce Ackerman, We the People: Transformations (2000).

160. 5 U.S. 137 (1803).

161. Establishment of the Judicial Courts of the United States, 1 Stat. 73 (1789).

162. Id.

163. See generally Mark A. Graber, Establishing Judicial Review: Marbury and the Judicial Act of 1789, 38 Tulsa L. ReV. 609 (2003); Mark A. Graber, James Buchanan as Savior? Judicial Power, Political Fragmentation, and the Failed 1831 Repeal of Section 25, 88 OR. L. REV. 95 (2009).

164. See WhitTington, supra note 58 , at 7.

165. See id. at 7-9.

166. See id.

167. See supra Part I.B.

168. See id.

169. See Whittington, supra note 58, and accompanying text.

170. See 6 FAIRmAn, supra note 120 , and accompanying text. 
agreement is that whether through motivation or structure, most legislation is based on interest satisfaction and most judicial decisions are based on legal principle.

Governing officials can successfully establish the political foundations for judicial review because certain critical features of American politics are either permanent or sufficiently enduring to ensure that at most periods in American history a stable group of political elites will have the opportunity to ensure that a supermajority on the Supreme Court has a consistent, self-conscious, and relatively public mission. Grand constitutional theorists maintain that unchanging characteristics of American politics provide political foundations for judicial supremacy. ${ }^{171}$ Presidents almost always appoint justices committed to exercising the power of judicial review because Americans have always been committed to the general principles underlying judicial supremacy, except perhaps during short realignment periods. Whittington explains why, with the exception of a few reconstructive presidents, presidents have historically sought to empower courts as allies against other factions in their party or rival partisan majorities in Congress. ${ }^{172}$ Regime theorists maintain that the unchanging features of longstanding constitutional orders provide political foundations for judicial supremacy. ${ }^{173}$ William Howard Taft's effort to stack the Supreme Court with conservatives ranged over three decades. ${ }^{174}$ Kevin McMahon details how racial liberals in the Justice Department over three presidencies successfully created a strong racially liberal majority on the Supreme Court. ${ }^{175}$ Both efforts were successful because, although the particular occupants of executive offices changed, the constitutional politics that generated conservative supporters of the freedom of contract and then liberal opponents of Jim Crow remained relatively constant.

Justices given a mission by a stable group of governing officials should produce a principled, or at least a consistent course of decisions. Grand constitutional theorists expect a theoretically consistent course of decisions. A liberal Court will decide consistently with the liberalism of John Locke, John Stuart Mill, or John Rawls. Regime theorists expect a politically consistent course of decisions. A liberal Court will decide consistently with the liberalism of Hillary Clinton or Barack Obama. The point of agreement is that constitutional politics typically generates a stable group of elites who empower a supermajority of the justices to undertake a constitutional mission and judicial decisions over long periods of time are or should be consistent with that constitutional mission.

\section{Judicial Supremacy in the Long State of Courts and Parties}

Grand constitutional and regime theory paint a fairly accurate description of

171. See supra Part I.A.

172. WhitTington, supra note 58.

173. See supra Part I.B.

174. See generally Walter F. Murphy, In His Own Image: Mr. Chief Justice Taft and Supreme Court Appointments, 1961 Sup. CT. REV. 159 (1961).

175. MCMAHON, supra note 61. 
how constitutional politics generated judicial supremacy through much of the late nineteenth and twentieth centuries. Conservatives during the first half of this period and liberals during the second half of this period empowered courts to embark on a favorable line of judicial decision making. They did so because the non-ideological parties of this period were not good vehicles for pursuing broad constitutional visions. They were able to achieve this because conservatives largely controlled the judicial appointment process from the 1890 s until the New Deal and liberals largely controlled the judicial appointment process from the New Deal until the end of the Great Society. Federal courts responded to these efforts to provide political foundations for a course of judicial decisions. Conservative efforts to pack the Court with conservatives during the first three decades of the twentieth century were rewarded by a series of decisions that limited state and federal power to regulate commercial activities. ${ }^{176}$ Liberal efforts to pack the Court with liberals during the next four decades were rewarded by a series of decisions that protected the rights of political dissenters and advanced the cause of racial equality. ${ }^{177}$

The American constitutional regime from the end of the nineteenth century to the end of the twentieth century might be described as "long state of courts and parties." 178 Stephen Skowronek coined the phrase "state of courts and parties" to describe the American constitutional order from 1877 until $1920 .{ }^{179}$ Courts in this regime made substantive rules for governance; parties divided the spoils of government. ${ }^{180}$ A similar division of labor developed during the New Deal. Courts resolved the constitutional issues that divided Americans; parties divided the spoils of government and delegated other decisions to administrative agencies or independent regulatory commissions. ${ }^{181}$ The primary differences between the first and second state of courts and parties are threefold:

1. Courts got out of the business of making economic policy because such matters as the appropriate scope of federal power under Article I and the regulation of business were no longer thought to raise constitutional questions. $^{182}$

2. Courts became far more permissive of legislative delegations to executive agencies and independent regulatory commissions. ${ }^{183}$ The successor to the first state of courts and parties might be better labeled as the state of courts,

176. See, e.g., Hammer v. Dagenhart, 247 U.S. 251 (1918), overruled by United States v. Darby, 312 U.S. 100 (1941).

177. See, e.g., Shelley v. Kraemer, 334 U.S. 1 (1948).

178. Graber, supra note 36.

179. SKOWRONEK, supra note 38 , at 38 .

180. Id. at 39-42.

181. Schechter Poultry Corp. v. United States, 295 U.S. 495, 551 (1935).

182. See generally Williamson v. Lee Optical, Inc., 348 U.S. 483 (1955); Wickard v. Filburn, 317 U.S. 111 (1942).

183. Compare Schechter Poultry Corp., 295 U.S. 495, with Yakus v. United States, 321 U.S. 414 (1944). 
parties, bureaucrats, and administrators.

3. Presidents of both parties regularly appointed liberals rather than conservatives to the federal bench. ${ }^{184}$

These developments altered neither the basic structure of partisan competition nor the political foundations for judicial supremacy. What changed between the first and second states of courts and parties were the location of the line between policy and constitutional decisions, the institutions that made policy decisions, and the ideology of the justices making constitutional decisions.

American constitutional politics during the long state of courts and parties was structured by an elite consensus on fundamental constitutional values. Howard Gillman demonstrated that during the Lochner Era, conservative elites in both the Democratic and Republican Party shared a general commitment to the freedom of contract or, more accurately, the principle that government could not favor one side to a commercial bargain unless the party was in particular need of state protection ${ }^{185}$ or the favoritism served a clear public interest. ${ }^{186}$ Lucas Powe demonstrated that, after the New Deal, liberal elites in both the Democratic and Republican Party shared a general commitment to protecting free speech and racial minorities. ${ }^{187}$ The existence of an elite consensus remained constant throughout much of the twentieth century, even as the content of that consensus changed significantly. Although elites were the leading proponents of scientific racism at the turn of the twentieth century, by the New Deal, elites had become the strongest proponents of racial equality. ${ }^{188}$

Supreme Court decision making reflected this elite consensus. During the last decades of the nineteenth century and first third of the twentieth century, the Supreme Court in such cases as Lochner v. New York ${ }^{189}$ and Hammer v. Dagenhart ${ }^{190}$ protected the freedom of contract and insisted on a sharp distinction between interstate commerce, which Congress could constitutionally regulate, ${ }^{191}$ and intrastate commerce, which Congress could not. ${ }^{192}$ Even the more liberal justices appointed before 1933 accepted the interstate/intrastate commerce distinction, ${ }^{193}$ though they questioned where conservative justices drew the line

184. Mark A. Graber, Not the Warren Court (or Deja-Vu All Over Again), BALKINIZATION (July 5, 2016, 6:03 PM), http://balkin.blogspot.com/2016/07/not-warren-court-or-deja-vu-allover.html [https://perma.cc/FKJ6-8YCJ].

185. In essence, the statutory distinctions were based on real differences between the affected classes.

186. See generally Howard Gillman, The Constitution Besieged: The Rise and Demise of Lochner Era Police Powers Jurisprudence (1993).

187. Powe, supra note 61.

188. Graber, The Coming Constitutional Yo-Yo, supra note 10, at 675-76.

189. 198 U.S. 45 (1905).

190. 247 U.S. 251 (1918).

191. Houston, E. \& W. Tex. Ry. Co. v. United States, 234 U.S. 342, 350 (1914).

192. United States v. E.C. Knight Co., 156 U.S. 1, 17 (1895).

193. Schechter Poultry Corp. v. United States, 295 U.S. 495, 544 (1935). 
between the two. ${ }^{194}$ Supreme Court decision making during the 1950 s and $1960 \mathrm{~s}$ consistently mirrored elite opinion on almost all issues on which public opinion surveys found that Democratic and Republican elites agreed more with each other than they did with fellow non-elite partisans. ${ }^{195}$ Elites, legal elites in particular, were far more inclined than the general public to favor free speech rights and the rights of persons suspected of crimes, and so were Supreme Court justices. During the late nineteenth century, when elites interested in promoting reconciliation with the South lost interest in protecting the rights of persons of color,${ }^{196}$ the Supreme Court handed down such decisions as Plessy v. Ferguson, ${ }^{197}$ Williams v. Mississippi, ${ }^{198}$ and Giles v. Harris. ${ }^{199}$ During the middle of the twentieth century, when elites rejected scientific racism, ${ }^{200}$ the Supreme Court handed down such decisions as Brown v. Board of Education, ${ }^{201}$ Bolling v. Sharpe ${ }^{202}$ and Loving v. Virginia. ${ }^{203}$

The connection between elite opinion and Supreme Court decision making was consistent, self-conscious, and moderately public. Walter Murphy and David Danelski detailed how William Howard Taft and his political allies successfully campaigned from 1908 until 1930 to staff the federal judiciary with justices committed to their conservative vision of constitutional political economy. ${ }^{204}$ This campaign was non-partisan. Taft, as President, appointed both conservative Democrats and conservative Republicans to the Supreme Court. ${ }^{205}$ Kevin McMahon detailed the Roosevelt Administration's effort to staff the federal judiciary with racial liberals. ${ }^{206}$ This campaign was also bipartisan. The Eisenhower Administration was as committed to providing the political foundations for judicial activism on behalf of persons of color as previous Democratic administrations. ${ }^{207}$ Both Democrats and Republicans in the White

194. See generally Carter v. Carter Coal Co., 298 U.S. 238 (1936).

195. Graber, The Coming Constitutional Yo-Yo?, supra note 10 at 685-92. See generally Herbert McClosky, Consensus and Ideology in American Politics, 58 Am. Pol. SCI. Rev. 361 (1964).

196. See generally David W. Blight, Race and Reunion: The Civil War in American Memory (2001); see also Paul Finkelman, Civil Rights in Historical Context: In Defense of Brown, 118 HARV. L. REV. 973, 1003-05 (2005).

197. 163 U.S. 537 (1896).

198. 170 U.S. 213 (1898).

199. 189 U.S. 475 (1903).

200. Michael Klarman, From Jim Crow to Civil Rights 210-11 (2004)

201. 347 U.S. 483 (1954).

202. 347 U.S. 497 (1954).

203. 388 U.S. 1 (1967).

204. See generally David J. Danelski, A Supreme Court Justice Is Appointed (1964); Murphy, supra note 174.

205. Kathleen M. Sullivan \& Noah Feldman, Constitutional Law 1621 (Robert C. Clark et al. eds., 18th ed. 2013).

206. See MCMAHON, supra note 61.

207. Id. 
House during the years immediately before $\mathrm{Brown}^{208}$ nominated members of the rival party for Supreme Court positions. ${ }^{209}$ What mattered was the judicial nominee's commitment to liberal elite values, particularly on racial issues, not the personal reasons why that nominee had cast his lot with one non-ideological party or the other.

The stability of the bipartisan conservative elite consensus, before the New Deal, and the bipartisan liberal elite consensus, after the New Deal, immunized the course of judicial decision making from the vagaries of individual justices and judicial vacancies except during the transition period from 1933 until 1937, when the lack of a judicial vacancy during Roosevelt's first term may have delayed the formation of the new liberal majority by a year or two. ${ }^{210} \mathrm{~W}$ ith the exception of Oliver Wendell Holmes, Jr., Louis Brandeis, and John Clarke, every justice appointed to the Supreme Court during the four decades before Franklin Roosevelt assumed the presidency maintained that the Due Process Clause of the Fifth and Fourteenth Amendments limited government power to interfere with private bargains. ${ }^{211}$ The close votes in such cases as Lochner, ${ }^{212}$ Wilson v. New, ${ }^{213}$ and Adkins v. Children's Hospital ${ }^{214}$ demonstrated that the timing of judicial appointments might have influenced the line between constitutional and unconstitutional interference with private bargains. ${ }^{215}$ However, unanimous case decisions, or near unanimous, in Adair v. United States, ${ }^{216}$ Coppage v. Kansas,${ }^{217}$ and Buchanan v. Warley, ${ }^{218}$ make clear that the vast majority of persons who could have plausibly been considered for a Supreme Court position during the decades immediately preceding the New Deal accepted the basic constitutional principles underlying the freedom of contract. ${ }^{219}$ The singular is appropriate when

208. 347 U.S. 483 (1954).

209. Sullivan \& Feldman, supra note 205, at 1622.

210. Id.

211. See infra notes $212-26$ and accompanying text.

212. 198 U.S. 45 (1905).

213. 243 U.S. 332 (1917).

214. 261 U.S. 525 (1923).

215. Had Wilson appointed a third progressive instead of James McReynolds, the justices in Hammer v. Dagenhart, 247 U.S. 251 (1918), would have probably ruled that Congress could prohibit shipping goods made with child labor in interstate commerce.

216. 208 U.S. 161 (1908).

217. 236 U.S. 1 (1915).

218. 245 U.S. 60 (1917).

219. The progressive John Clarke contributed to the revival of the freedom of contract during the 1920s when he resigned after only six years on the Court and was replaced by the very conservative George Sutherland. See George Sutherland, in The Supreme Court Justices: A Biographical Dictionary 448, 449 (Melvin Urofsky ed., 1990). On the other hand, Oliver Wendell Holmes, Jr., slowed the revival of the freedom of contract because, despite being the oldest justice on the Supreme Court by almost a decade, Holmes remained on the bench through the 1920s. See Oliver Wendell Holmes, Jr., in The Supreme Court Justices: A Biographical DiCTIONARY 224, 225-26 (Melvin Urofsky ed., 1990). In short, had a more normal judicial 
speaking of the jurisprudence of the Fuller, White, and Taft Courts because a supermajority on those tribunals shared a common constitutional commitment to classical constitutionalism, ${ }^{220}$ even as the justices disputed how to apply certain shared principles to specific cases. Every Warren Court justice was a liberal activist on race. The close votes in cases involving the constitutional rights of civil rights protestors ${ }^{221}$ demonstrate that the timing of judicial appointments could have influenced the line between constitutionally protected and constitutionally unprotected civil rights demonstrations, but the unanimous judicial decisions in such cases as Brown, ${ }^{222}$ Loving,${ }^{223}$ and New York Times Co. v. Sullivan ${ }^{224}$ make clear that almost every person who could have been plausibly considered for a Supreme Court appointment during the decades immediately after the New Deal would have joined the judicial crusade against Jim Crow. ${ }^{225}$ The singular is also appropriate when speaking of the jurisprudence of the Warren Court because a supermajority on that tribunal shared a common constitutional commitment to a liberal version of living constitutionalism, ${ }^{226}$ even as the justices disputed how to apply certain shared principles to specific cases.

Taft and Franklin Roosevelt empowered federal courts because their parties were not united on any constitutional vision. Taft's Republican Party had a strong progressive wing that opposed the freedom of contract and favored extensive, for that time, federal regulation on commercial affairs. ${ }^{227}$ Roosevelt's Democratic Party was the coalition of choice for the solid South, which regularly supplied the federal government with racist legislators who could be counted on to veto any legislation that might have some impact on race relations in the former Confederate states. ${ }^{228}$ Individual Democrats and Republicans in this time period were motivated by constitutional principles, but legislatures structured by badly

secession taken place, Sutherland would have replaced Holmes rather than Clarke, a substitute that would have had no impact on the course of judicial decision making during the $1920 \mathrm{~s}$.

220. See Gillman, supra note 186.

221. See, e.g., Adderly v. Florida, 385 U.S. 39 (1966); Bell v. Maryland, 378 U.S. 226 (1964).

222. 347 U. S. 483 (1954).

223. 388 U.S. 1 (1967).

224. 376 U.S. 254 (1964). For the reasons Sullivan is best classified as a race case, see KERMIT L. Hall \& Melvin I. Urofsky, NeW York Times V. Sullivan: Civil Rights, Libel LaW, and the FreE PRESS (2011).

225. Warren Court liberalism on race and other matters would, if anything, have accelerated if all justices had left the Court at age seventy. See Sullivan \& FELDMAN, supra note 205, at 1622. Frank Murphy and Wiley Rutledge, the two most liberal justices on the Stone Court, died in their mid-fifties. See id. Felix Frankfurter would not have been on the Brown Court (the arch segregationist, James Byrnes, who resigned after only a year on the bench, would have left in 1949). See id.

226. See 2 Howard Gillman et Al., American Constitutionalism: Rights And LIBERTIES 485 (2012).

227. See Progressive Party Platform of 1912, Am. Presidency Project (Nov. 5, 1912), http://www.presidency.ucsb.edu/ws/index.php?pid=29617 [https://perma.cc/J5Z2-YVAM].

228. See MCMAHON, supra note 61. 
divided parties on these constitutional matters could not decide whether to endorse or condemn the freedom of contract or racial segregation. Justice Robert Jackson observed at oral argument in Brown, "I suppose that realistically the reason this case is here is that action couldn't be obtained from Congress." ${ }^{229}$ Although Jackson was referring to the "action" of desegregating schools, his observation held for any action Congress might take on Jim Crow. A bill affirming separate but equal would have been as surely blocked by congressional liberals as bills providing civil rights were blocked by southern Democrats.

Political scientists documented and bemoaned the structure of partisan competition during the long state of courts and parties. Conventional wisdom maintained that politics was dominated by interest groups that were more concerned with providing benefits to members than taking stands on constitutional principle. ${ }^{230}$ Anthony Downs and David Mayhew wrote influential works, each claiming that elected officials were motivated primarily by the possibility of being re-elected. ${ }^{231}$ Downs maintained that the re-election incentive guaranteed that both major parties in a two party system cleaved to the middle. ${ }^{232}$ Mayhew maintained that representatives seeking re-election primarily engaged in constituency service and position-taking, rather than engaging with the constitutional issues of the day. ${ }^{233}$ In 1946, the American Political Science Association complained:

Historical and other factors have caused the American two-party system to operate as two loose associations of state and local organizations, with very little national machinery and very little national cohesion. As a result, either major party, when in power, is ill-equipped to organize its members in the legislative and the executive branches into a government held together and guided by the party program. Party responsibility at the polls thus tends to vanish. ${ }^{234}$

Inspired by the political science of their generation, Bickel, Wechsler, and fellow grand constitutional theorists assumed that the structure of partisan conflict during the long state of courts and parties was an enduring characteristic of American constitutionalism. Judicial supremacy flowed from a constitutional order structured by non-ideological parties and an elite consensus on constitutional principles. During the long state of courts and parties, the Supreme Court could rarely be said to be thwarting the will of the representatives of the

229. Powe, supra note 61, at 47 (quoting Justice Robert Jackson).

230. See generally Arthur F. Bentley, The Process of Government: A Study of Social Pressures (1908); David B. Truman, The Governmental Process: Political Interests And Public OpINION (1951).

231. See generally Anthony Downs, An Economic Theory of Democracy (1957); David R. Mayhew, Congress: The Electoral Connection (1974).

232. Anthony Downs, An Economic Theory of Democracy 114-41 (1957).

233. David R. Mayhew, Congress: The Electoral Connection 61-73 (1974).

234. Am. Political Sci. Ass'n, Toward a More Responsible Two-Party System: A REPORT, at v (1950). 
people of the here and now in any strong sense because, with rare exceptions, elections were not fought over the issues that courts adjudicated. Republicans and Democrats as a whole did not present voters with different choices on the freedom of contract during the Lochner $\mathrm{Era}^{235}$ or the right to desegregated schools in the Brown Era. ${ }^{236}$ Both before and after the New Deal, the executive branch was staffed by a stable group of governing officials who made consistent, selfconscious, and relatively public efforts to provide the political foundations for the particular course of judicial decisions that the justices eventually took. When elections gave the winners a constitutional mandate, the Supreme Court had either been supporting the winning side $(1896)^{237}$ or quickly fell in line (1936). ${ }^{238}$ The twentieth century was the heyday for judicial supremacy because the constitutional politics of that century generated judicial supremacy.

\section{JUDiCIAL SUPREMACY IN THE ERA OF DIVIDED GOVERNMENT AND POLARIZED POLITICS}

Grand constitutional and regime theory paint a poor picture of constitutional politics during the late twentieth century and the first decades of the twenty-first century. A regime structured by two ideological parties, polarized elites, divided government, and electoral instability has replaced the long state of courts and parties. The Democratic and Republican Parties advance distinctive constitutional visions, eschewing centrist interest balancing. Elite polarization has replaced the bipartisan elite consensus of the past. Democratic and Republican elites more vehemently disagree with each other on constitutional issues that do less elite partisans. Each party usually controls one, but not all, of the elected branches of the national government, with control of the presidency rotating every decade.

This new constitutional order transformed judicial politics and the political foundations for Supreme Court decision making. Sustained and bitter debates routinely take place over the confirmation of any person with some responsibility for interpreting the Constitution of the United States. Not only have Supreme Court nominations become brawls, but intense controversies occur over the staffing of the lower federal courts, state courts, and the Justice Department. ${ }^{239}$

235. Neither the Republican nor Democratic Party Platform in 1908 mentioned Lochner or any issue relevant to the freedom of contract. See Republican Party Platform of 1908, AM. PRESIDENCY ProjeCt (June 16, 1908), http://www.presidency.ucsb.edu/ws/index.php?pid=29632 [https:// perma.cc/EXD3-XGVD]; 1908 Democratic Party Platform, AM. Presidency Project (July 7, 1908), http://www.presidency.ucsb.edu/ws/index.php?pid=29589 [https://perma.cc/4P25-MPU5].

236. For the similarity between Republican and Democratic Party Platforms on race from the New Deal until the Great Society, see 2 GILlMAN ET AL., supra note 226, at 580.

237. See generally Alan Furman Westin, The Supreme Court, the Populist Movement and the Campaign of 1896, 15 J. POL. 3 (1953).

238. See generally William E. Leuchtenburg, The Supreme Court Reborn: The Constitutional Revolution in the Age of Roosevelt (1995).

239. See generally Charles Gardner Geyh, Courting Peril: The Political Transformation of THE American Judiciary (2016); MARK Silverstein, Judicious Choices: The New Politics of Supreme Court Confirmations (1994). 
The federal judiciary in this era of polarized politics and divided government no longer has a mission generated by a stable consensus within the political system. Judicial decisions are activist, erratic, and random. Developments in constitutional law result from accidents that affect the timing of judicial appointments rather than consistent, self-conscious, and relatively public decisions made over a period of years by accountable governing officials.

American politics for the past thirty years has been structured by two ideological parties with divergent constitutional commitments. Republicans being conservative and Democrats being liberal. The liberal Republicans and conservative Democrats who once roamed the halls of Congress and the executive branch are extinct, a development that accelerates political extremism while handicapping more traditional interest group bargaining. ${ }^{240}$ The contemporary Republican and Democratic Parties champion very different constitutional approaches and visions. Republicans are originalists while Democrats celebrate a living constitution. ${ }^{241}$ The two parties offer voters distinctive positions on most major constitutional issues of the day. ${ }^{242}$ Republican Party platforms advocate constitutional protections for gun owners and evangelical Christians. ${ }^{243}$ Democratic Party platforms support constitutional protections for same-sex couples and women seeking abortions. ${ }^{244}$

Polarization is particularly acute among elites, who exercise disproportionate influence on electoral politics and even greater influence on judicial politics. ${ }^{245}$ Recent surveys suggest that the greater their socio-economic status, the more likely Republicans will take strong conservative positions on all the constitutional issues of the day and the more likely Democrats will take strong liberal positions on those constitutional issues. ${ }^{246}$ Political scientists refer to this phenomenon as "conflict extension." 247 Geoffrey Layman and Thomas Carsey observe "a growth

240. See generally Nicol C. Rae, Southern Democrats (1994); Nicol C. Rae, The Decline And Fall of Liberal Republicans: From 1952 to the Present (1989).

241. See 2 Gillman ET AL., supra note 226, at 886.

242. See generally H.W. Perry, Jr. \& L.A. Powe, Jr., The Political Battle for the Constitution, 21 Const. Comment. 641 (2004).

243. We Believe in America, 2012 Republican Platform, http://www.presidency. ucsb.edu/papers_pdf/101961.pdf [https://perma.cc/X8ZX-MUUV] (last visited Oct. 20, 2016).

244. Moving America Forward: 2012 Democratic National Platform, Am. Presidency PROJECT (Sept. 3, 2012), http://www.presidency.ucsb.edu/ws/index.php?pid=101962 [https://perma. cc/VZN5-BJDU].

245. See Lawrence Baum \& Neal Devins, Why the Supreme Court Cares About Elites, Not the American People, 98 GEO. L.J. 1515, 1580-81 (2010); Graber, The Coming Constitutional Yo-Yo?, supra note 10.

246. See The 2005 Political Typology, The Pew Res. Ctr. (May 10, 2005, 4:00 PM), http://www.people-press.org/files/legacy-pdf/242.pdf[https://perma.cc/MCG5-882N]; Beyond Red vs. Blue: Political Typology, Pew ReS. CTR. (May 4, 2011), http://www.people-press.org/ files/legacy-pdf/Beyond-Red-vs-Blue-The-Political-Typology.pdf[https://perma.cc/MQ5X-JVLC]; Graber, The Coming Constitutional Yo-Yo?, supra note 10, at 695-700.

247. See generally Geoffrey C. Layman \& Thomas Carsey, Party Polarization and "Conflict 
in mass party polarization on multiple distinct issue dimensions" with elites. ${ }^{248}$ Further, they commented on how Americans are "more polarized on social welfare, racial, and cultural issues" than at any other time in American history. ${ }^{249}$

Divided government and electoral instability also characterize and structure contemporary constitutional politics. For the past forty-eight years, partisan control over national institutions has been divided three-quarters of the time (thirty-six out of forty-eight years). ${ }^{250}$ No governing coalition has maintained control over all national elected institutions for more than four years. Presidents from different parties alternate in the White House. If President George H.W. Bush is considered President Ronald Reagan's "third-term understudy,"251 then representatives from the two major parties have taken turns occupying the presidency since 1964. To the extent the probable election of Hillary Clinton suggests a different pattern, ${ }^{252}$ that pattern is likely to be a relatively strong Democratic lock on the presidency and a relatively strong Republican lock on at least one House of Congress.

This combination of ideological parties, polarized politics, divided government, and electoral instability is best conceptualized as a distinctive regime or constitutional order rather than as a transitional period between the long state of courts and parties, or the Reagan Era, and something else. ${ }^{253}$ The crucial features of the contemporary era are relatively enduring, having structured American politics for at least three decades. If anything, the main characteristics of this constitutional order are becoming more entrenched. Four of the five most recent national elections have resulted in divided government. ${ }^{254}$ Odds are high that government will remain divided after the 2016 national election. Surveys show no end to elite polarization. ${ }^{255}$ The strong showing of candidates at the extreme of both parties during the 2016 party primaries and their success in pushing the more mainstream candidates further right or left suggest that partisan polarization is intensifying. ${ }^{256}$

Extension" in the American Electorate, 46 AM. J. POL. SCI. 786 (2002).

248. Id. at 789.

249. Id. at 786 .

250. Walter Burnham, The Politics of Repudiation 1992: Edging Toward Upheaval, АM. PROSPECT (1993), http://prospect.org/article/politics-repudiation-1992-edging-toward-upheaval [https://perma.cc/WHX9-BZHU].

251. Id.

252. Hillary Clinton, if elected, may just be a third-term understudy. See Murphy, supra note 174.

253. But see Jack M. Balkin, The Last Days of Disco: Why the American Political System Is Dysfunctional, 94 B.U.L. REV. 1159, 1193 (2014).

254. See A Visual Guide: The Balance of Power Between Congress and the Presidency: 19452010, U.S.POLITICS, http://uspolitics.about.com/od/usgovernment/1/bl_party_division_2.htm(last visited Oct. 20, 2016).

255. See supra notes $245-47$ and accompanying text.

256. See Jonathan Rauch, How American Politics Went Insane, Atlantic, July/Aug. 2016, http://www.theatlantic.com/magazine/archive/2016/07/how-american-politics-went-insane/485570/ 
Ideological parties, elite polarization, divided government, and electoral instability exacerbate conflicts over the federal (and state) judiciaries. ${ }^{257}$ Ideological parties and polarized elites have an obvious interest in controlling the institution that the long state of courts and parties charged with the primary responsibility for articulating fundamental values. Divided government makes courts a crucial tie-breaker. Democrats and Republicans cannot achieve their constitutional goals in electoral politics, at least if their goal is not gridlock, because the rival almost always controls at least one crucial veto point. Hence, on issues as diverse as campaign finance, same-sex marriage, gun regulation, and affirmative action, conservatives and liberals launch litigation campaigns to obtain favorable judicial rulings, knowing that the victorious faction in Court will control at least one veto point outside the judiciary that can be used to prevent the elected branches from interfering with their litigation success.

The same structure of partisan competition that creates the political gridlock that incentivizes constitutional litigation practically ensures that neither conservatives nor liberals will obtain a course of favorable judicial decisions for any length of time. In sharp contrast to the way in which the combination of nonideological parties and a bipartisan elite consensus generated justices during the long state of parties who worked within a common constitutional framework, the combination of ideological parties, elite polarization, divided government, and electoral instability generates a federal judiciary equally divided between political liberals appointed by Democrats and political conservatives appointed by Republicans. ${ }^{258}$ The resulting course of Supreme Court decisions depends on the idiosyncrasies of one or two swing justices, who on some issues lean to the left, on others lean to the right, and sometimes find middle positions whose constitutional logic escapes a majority of their brethren. Some presidents turn to "stealth nominees," 259 whose constitutional opinions could not be ascertained with any degree of certainty, at least by persons outside the executive branch. The singular is not appropriate when speaking of the jurisprudence of the Rehnquist and Roberts Courts because no majority on those tribunals ever shared a common constitutional vision that guided their decisions and cabined their disagreements. $^{260}$

The combination of many strong partisans with one or two eccentric centrists disconnects the course of judicial decision making from the rest of the political system. The Rehnquist and Roberts Courts are the first tribunals in American history to simultaneously engage in liberal and conservative judicial activism. ${ }^{261}$

[https://perma.cc/8].

257. See supra notes 253-56 and accompanying text.

258. The argument in this paragraph is more fully developed in Belling the Partisan Cats. See Graber, supra note 10.

259. Geoffrey R. Stone, Understanding Supreme Court Confirmations, 2010 SuP. CT. REV. 381, 438 (2011).

260. See Michael J. Klarman, Majoritarian Judicial Review: The Entrenchment Problem, 85 GEO. L.J. 491, 548-49 (1997).

261. See id. at 548. 
Michael Klarman in 1997 observed:

When Justices O'Connor and Kennedy are in their conservative mode, affirmative action, minority voting districts, hate speech regulations, and environmental land use restrictions are all constitutionally suspect.... When these pivotal Justices are in their liberal mode, abortion restrictions, school prayer, restrictions on gay rights, exclusion of women from VMI, and limitations on the right to die fall victim to the Court's constitutional axe. ${ }^{262}$

The next two decades added gun regulations $\mathrm{s}^{263}$ and restrictions on religious ${ }^{264}$ or expressive organizations ${ }^{265}$ to the conservative ledger, and restrictions on who and what crimes are eligible for the death penalty to the liberal ledger. ${ }^{266}$ The day after the Supreme Court declared unconstitutional the preclearance formula Congress mandated under the Voting Rights Act, ${ }^{267}$ the justices struck down a crucial provision of the Defense Against Marriage Act. ${ }^{268}$ This course of judicial decision making does not reflect the constitutional vision of any political party, prominent faction within a political party or consensus within a bipartisan elite, or, for that matter, any academic justification of judicial review. Laurence Tribe gave up writing a new edition of his treatise because he developed "profound doubts whether any new synthesis" of contemporary American constitution law "is possible at present." 269

Random events move this ideologically erratic course of judicial decision making. Changes in the course of judicial decision making are often random in part because tiebreaking votes are typically cast by the one or two justices with idiosyncratic, if not eccentric, constitutional beliefs that could not be predicted before they joined the Court. Justice Stephen Breyer was the only member of the Rehnquist Court, if not the American constitutional universe, who discerned a constitutional distinctive between a display of the Ten Commandments in a courthouse and a display of the Ten Commandments in a public park adjoining the state capitol. ${ }^{270}$ Justice Kennedy developed a strong commitment to gay rights after joining the federal bench. ${ }^{271}$ Changes are also random because they hinge

262. Id. at 548-49.

263. See generally District of Columbia v. Heller, 554 U.S. 570 (2008).

264. See generally Good News Club v. Milford Cent. Sch., 533 U.S. 98 (2001).

265. See generally Boy Scouts of Am. v. Dale, 530 U.S. 640 (2000).

266. See, e.g., Kennedy v. Louisiana, 554 U.S. 407 (2008); Roper v. Simmons, 543 U.S. 551 (2005).

267. Shelby Cty. v. Holder, 133 S. Ct. 2612, 2631 (2013). This case was handed down on June 25, 2013.

268. United States v. Windsor, 133 S. Ct. 2675, 2696 (2013). This case was handed down on June 26, 2013.

269. Laurence H. Tribe, The Treatise Power, 8 GreEn BAG 2d 291, 295 (2005).

270. See generally McCreary Cty. v. ACLU, 545 U.S. 844 (2005); Van Orden v. Perry, 545 U.S. 677 (2005).

271. See Lisa K. Parshall, Redefining Due Process Analysis: Justice Anthony M. Kennedy and 
more than ever on the timing of judicial vacancies. Many justices try to preserve an existing course of judicial decision making by leaving the bench at a time when they are confident the President will appoint an ideologically compatible successor. ${ }^{272}$ Others do not want to retire, retire for personal reasons that cannot be planned, or unexpectedly die. ${ }^{273}$ The end result is that no good way exists of predicting which party will have control of the White House and Senate when crucial judicial nominations are made or what constitutional vision will animate the governing elite responsible for vetting potential justices.

The aftermath of Justice Scalia's death vividly demonstrates how developments in contemporary constitutional law depend on random accidents. Had Justice Scalia survived another six months, the Supreme Court would have dealt death blows to public sector unions, ${ }^{274}$ permanently enjoined the enforcement of the Obama administration's immigration policies ${ }^{275}$ and expanded state sovereign immunity. ${ }^{276} \mathrm{~A}$ high probability exists that the justices by a 5-4 vote would have ruled that religious employers may legally refrain from filling out forms notifying insurance companies that they will not pay for their employees to have contraceptive services. ${ }^{277}$ Had Justice Ruth Bader Ginsburg, who has had health issues, ${ }^{278}$ passed away rather than Scalia, the use of affirmative action would have been sharply curtailed ${ }^{279}$ and the abortion regulations at issue in Whole Women's Health v. Hellersted ${ }^{280}$ would have been sustained by a $4-4$ vote.

These random movements are more basic to the contemporary constitutional order than the ideologically erratic course of recent decision making. Random events sometimes enable an ideological party to gain the bare majoritarian control over the Supreme Court necessary to produce a coherent line of decisions for a short period of time. The Supreme Court may be on the verge of having a fivejustice liberal majority. Some commentators believe the Supreme Court had previously been controlled by a five-justice conservative majority. ${ }^{281}$ These majorities, however, are caused by the timing of judicial vacancies rather than by a stable group of governing officials gaining control over the institutions

the Concept of Emergent Rights, 69 AlB. L. REV. 237, 281 (2005) ("While serving on the Ninth Circuit from 1975-1987, Justice Kennedy had confronted gay rights issues in five cases, ruling against the gay claimant in every instance.").

272. See generally David N. Atkinson, Leaving the Bench: Supreme Court Justices at THE END (1999).

273. $I d$.

274. See generally Friedrichs v. Cal. Teachers Ass'n, 136 S. Ct. 1083 (2016).

275. See generally United States v. Texas, 136 S. Ct. 2271 (2016).

276. See generally Franchise Tax Bd. v. Hyatt, 136 S. Ct. 1277 (2016).

277. See generally Zubik v. Burwell, 136 S. Ct. 1557 (2016).

278. See Adam Liptak, Justice Ginsburg Undergoes Surgery for Pancreatic Cancer, Court Says, N.Y. Times, Feb. 6, 2009, at A12.

279. See generally Fisher v. Univ. of Tex. at Austin, 136 S. Ct. 2198 (2016).

280. 136 S. Ct. 2292 (2016).

281. See Balkin, supra note 253, at 1160. 
responsible for staffing and influencing the federal judiciary. Democrats are on the verge of achieving a liberal majority on the Supreme Court because a conservative justice died on President Obama's watch, but no liberal justice died on the second President Bush's watch. ${ }^{282}$ Conservative judicial activism occurred because, although both Democrats and Republicans controlled the White House for twenty of the past forty years, Republican presidents appointed seven of the eleven Supreme Court justices who joined the bench after 1976. ${ }^{283}$

This erratic, random course of judicial decision making has political foundations, just not the political foundations presupposed by grand constitutional and regime theory. The structure of partisan politics explains why contemporary Supreme Court decision making is activist, erratic, and random. ${ }^{284}$ The course of Supreme Court decisions is activist because both Democrats and Republican presidents appoint to the federal bench justices they believe will carry out their activist constitutional agenda. Justices who propose mutual disarmament, Judge J. Harvie Wilkinson of the Court of Appeals for the Fourth Circuit comes to mind, ${ }^{285}$ need not apply for Supreme Court openings. The course of Supreme Court decisions is ideologically erratic because crucial votes are typical cast by justices with idiosyncratic views, whose eccentricities were not fully known or public when they were being considered for the bench. Justice Anthony Kennedy gained the judicial seat denied to Robert Bork because the degree of Kennedy's conservatism was far harder to assess than Bork's. ${ }^{286}$ The course of Supreme Court decision making is random because the balance of power on the Court depends on which justices, for personal or health reasons, do not time their leaving the bench to ensure replacement by an ideologically affiliated President. The course of judicial decision making during the 1990s was significantly influenced by Justices William Brennan and Thurgood Marshall not retiring during the Carter Administration, which gave the first President Bush the opportunity to determine their replacements. ${ }^{287}$

Governing officials establish the political foundations for contemporary

282. Both President Obama and the second President Bush replaced two ideologically allied justices.

283. See Members of the Supreme Court of the United States, SupremeCourT.gov (Aug. 6, 2016), https://www.supremecourt.gov/about/members.aspx [https://perma.cc/H2PQ-DDE2].

284. See supra notes 263-69 and accompanying text.

285. See generally J. Harvie Wilkinson, III, Cosmic Constitutional Theory: Why Americans ARe Losing Their InALIENABLE Right to SELF-Government (2012).

286. See David Alistar Yalof, Pursuit of Justice: Presidential Politics and the SElECtion OF SupREME COURT NomineEs 145-46 (1999) (noting from a conservative perspective "Kennedy's judicial record" as a lower federal court judge "revealed some striking inconsistencies").

287. Most notably, the Supreme Court would not have revived the interstate commerce clause and state sovereign immunity had a Carter appointee committed to the New Deal settlement been on the Court during the 1990s and first decade of the twenty-first century rather than Justice Clarence Thomas, who was appointed to replace Marshall in 1991. See, e.g., Alden v. Maine, 527 U.S. 706 (1999); United States v. Lopez, 514 U.S. 549 (1995). 
judicial activism by inaction after the justices make decisions rather than by proactively facilitating a course of decision making. During the long state of courts and parties, governing officials created political foundations for judicial power by taking "traceable steps through official actions that expand judicial powers or capacities." 288 During the state of polarized politics and divided government, governing officials establish political foundations for judicial activism by being incapable of responding after the justices have initiated a course of decisions. Members of Congress and the President "fail to take advantage" of "opportunities to negate, modify, or limit the effect of judicial rulings. ${ }^{289}$ The Supreme Court in the second decade of the twenty-first century is not carrying out a mission "traceable" to "official actions." 290 Neither conservative Republicans nor liberal Democrats have been able to sustain control of the crucial institutions necessary to forge a federal judiciary committed to a particular partisan constitutional vision. Instead, elected officials are passive (or passive-aggressive). The Supreme Court is presently free to move in a liberal, conservative, or erratic direction because any decision five justices reach in particular cases or any more general course of decision making will enjoy enough support in one elected branch of the national government to prevent retaliation against the federal judiciary. Liberal Democrats in control of the White House can be trusted to block any legislative initiative that might push constitutional practice or the Supreme Court in a more conservative direction. Conservatives in control of Congress can be trusted to block any executive initiative that might push constitutional practice or the Supreme Court in a more liberal direction. The Supreme Court is the institution that has the final say on such matters as abortion and affirmative action because the Supreme Court is presently the only institution capable of having a say on these matters. ${ }^{291}$

The contemporary federal judiciary is arguably more independent of electoral and legislative politics than at any time in American history. Neither the White House nor Congress presently has any political capacity to interfere with or influence a course of judicial decision making. President Obama cannot secure a more liberal judiciary through the appointment process because Republicans in Congress will not even hold hearings on his nominees. ${ }^{292}$ Republicans in Congress cannot inhibit judicial liberalism through jurisdiction stripping or

288. Lemieux \& Lovell, supra note 26, at 215.

289. Id. at 216 .

290. Id. at 215 .

291. More generally, the combination of ideological parties, polarized elites, divided government, and political instabilities rewards constitutional first movers. To the extent, for example, the President is able to take actions that have legal consequences, organizing the other two branches to block such actions is often difficult if not impossible.

292. See Jonathan Cohn, The Real Reason Republicans Won't Give Obama's Supreme Court Nominee a Hearing, HufFington Post (Mar. 17, 2016), http://www.huffingtonpost.com/ entry/merrick-garland-nomination_us_56e99eace4b0b25c91842ac2 [https://perma.cc/6R9D$4 \mathrm{H} 5 \mathrm{M}]$. 
similar legislation because President Obama will veto such legislation. ${ }^{293}$ John Marshall could only dream of a constitutional universe in which the Supreme Court was so free from presidential, legislative, or partisan threats. Whether this independence is actually desirable is another question.

\section{W HITHER JUDICIAL SUPREMACY}

The activist, ideologically erratic, and random course of contemporary Supreme Court decisions lacks the political foundations that justify judicial supremacy. No stable group of politically accountable governing officials has charged the federal judiciary with a consistent, self-conscious, and relatively public mission. The Court cannot be said to be carrying out the constitutional vision of the dominant political party because there is no dominant political party. The federal judiciary cannot be said to reflect an elite consensus on fundamental constitutional values because no such elite consensus exists. The justices cannot be said to be finding a middle position between political extremists ${ }^{294}$ because the capacity of the political system to generate centrist justices has been severely weakened. ${ }^{295}$ The justices cannot even be said to be settling fundamental constitutional issues ${ }^{296}$ because a high percentage of contemporary constitutional decisions are likely to be overruled or modified significantly should a judge in the majority happen to leave the bench at a time when the White House is occupied by a President of the other party. ${ }^{297}$

Judicial supremacy requires political foundations. Grand constitutional and regime theorists agree that the Supreme Court should be vested with the final say over what the constitution means only when carrying out missions generated by the rest of the political system. ${ }^{298}$ Grand constitutional theorists insist that the American people throughout history have consistently, self-consciously, and publicly authorized the Supreme Court to be the voice of constitutional principle in the American constitutional order. ${ }^{299}$ Regime theorists insist that fairly stable groups of governing elites at different times in American history have consistently, self-consciously, and relatively publicly authorized the Supreme Court to advance specific constitutional visions. ${ }^{300}$ Judicial supremacy is consistent with constitutional democracy, practitioners of grand constitutional and regime theory concur, when judicial supremacy is a democratic choice. ${ }^{301}$

293. See Tara Leigh Grove, The Structural Safeguards of Federal Jurisdiction, 124 HARv. L. REV. 869, 871 (2011).

294. See Mark A. Graber, Dred Scott as a Centrist Decision, 83 N.C. L. REv. 1229, 1268-69 (2005)

295. See Graber, The Coming Constitutional Yo-Yo?, supra note 10, at 710-11.

296. See generally Larry Alexander \& Frederick Schauer, On Extrajudicial Constitutional Interpretation, 110 HARV. L. REV. 1359 (1997).

297. See Graber, The Coming Constitutional Yo-Yo?, supra note 10, at 711-12.

298. See supra Part I.

299. See supra Part I.A.

300. See supra Part I.B.

301. See supra Part I.C. 
These political foundations may provide necessary rather than sufficient conditions for judicial supremacy. Grand constitutional theorists think that Supreme Court justices must act consistently with specific values when carrying out their mission to be the voice of principle in American constitutional politics. ${ }^{302}$ Justices, different commentators claim, must respect original meanings, advance democracy, promote human rights, or redeem inherited constitutional commitments. ${ }^{303}$ The extent to which such constitutional commitments are part of or in addition to the charge that governing officials and the American people give to the Supreme Court is not always clear.

Although no agreement exists on the best judicial mission, broad agreement exists among contemporary constitutionalists that a course of judicial decision making entirely disconnected from the rest of the political system should not settle constitutional controversies. Justices require the right kind of independence from the rest of the political system, not complete independence per se. Justices should not be selected or bullied for the purpose of advancing the political aspirations of their powerful elites. Nevertheless, justices within a constitutional order are and should be expected to carry out constitutional missions assigned to them by the American people as a whole or by a stable group of politically accountable governing officials, whether those missions be as general as "decide on constitutional principle" or as specific as "strike down racial segregation."

The course of Supreme Court decision making met these standards throughout much of the twentieth century. ${ }^{304} \mathrm{~A}$ stable group of politically accountable governing elites vested the federal judiciary with consistent, selfconscious, and relatively public missions. ${ }^{305}$ The governing officials who established the political foundations for judiciary supremacy were stable because the bipartisan elites most responsible for staffing and influencing the Supreme Court shared and acted on a common constitutional vision. ${ }^{306}$ Judicial missions were consistent because this elite bipartisan consensus ensured that the ideological composition of the Court did not depend on any particular election or the timing of judicial vacancies. ${ }^{307}$ Judicial missions were self-conscious because the governing officials who established the political foundations for judicial power intended to initiate the general course of decision making that actually occurred. ${ }^{308}$ Judicial missions were relatively public because Americans could fairly easily trace the course of judicial decision making to politically accountable governing elites responsible for establishing the political foundations for judicial power. ${ }^{309}$

302. See supra Part I.A.

303. See generally JACK M. BALKin, Constitutional Redemption: Political FAith in AN UNJUST WORLD (2011).

304. See supra Part II.

305. See id.

306. See id.

307. See id.

308. See id.

309. See id. 
These political foundations for judicial supremacy remained in place when the course of judicial decision making in the long state of courts and parties changed dramatically. ${ }^{310}$ The constitutional commitments of the American regime were altered when New Deal liberals replaced classical conservatives on the federal bench and in the elected branches of the national government. ${ }^{311}$ What did not change was the crucial characteristics of the long state of courts and parties that legitimated judicial power. ${ }^{312}$ During the decades immediately before and after the New Deal, a political order marked by two non-ideological parties and a bipartisan elite consensus generated consistent, self-conscious and public missions for the Supreme Court, even as that mission was transformed at the midpoint of that regime. ${ }^{313}$

Judicial supremacy was hardwired into the long state of courts and parties. ${ }^{314}$ The structure of partisan competition generated judicial power, particular judicial missions, and a governing elite that supported the resulting course of judicial decisions. $^{315}$ The combination of two non-ideological parties and a stable bipartisan elite consensus consistently, self-consciously, and relatively publicly directed crucial constitutional issues to a federal judiciary that was staffed with justices who shared the bipartisan elite consensus on those constitutional issues. ${ }^{316}$ Some version of the freedom of contract was hardwired into the first state of courts and parties, just as some version of racial liberalism was hardwired into the second state of courts and parties. ${ }^{317}$ The New York Times acknowledged the powerful connections between the Supreme Court and the rest of the political system by subheading a front page story the day after Brown was decided, "Ruling Tied to Eisenhower." 318 The Southern Democrats who blamed Brown on the executive branch of the national government understood that judicial supremacy during most of the twentieth century could not be attacked from within the long state of courts and parties. ${ }^{319}$ Fundamental changes had to take place in the entire constitutional order for constitutional authority to be reallocated. ${ }^{320}$ If the structure of partisan competition during the $1950 \mathrm{~s}$ was not transformed, the course of Supreme Court decision making could not be reversed. ${ }^{321}$

The course of judicial decision making during the twenty-first century lacks

310. See id.

311. See id.

312. See id.

313. See id.

314. See id.

315. See id.

316. See id.

317. See id.

318. William S. White, Ruling to Figure in '54 Campaign: Decision Tied to Eisenhower-Russell Leaders Southerners in Criticism of Court, N.Y TIMES, May 18, 1954, at 1.

319. See supra Part II.

320. See id.

321. See id. 
the political foundations that justify giving the Supreme Court final authority on the meaning of constitutional provisions. ${ }^{322}$ Contemporary constitutional politics does not generate a stable group of politically accountable governmental elites who provide political foundations for consistent, self-conscious, and relatively public judicial missions. ${ }^{323}$ The constitutional visions that animate the politically accountable governing elite most responsible for staffing and influencing the Supreme Court changes by the decade. ${ }^{324}$ The resulting judicial missions are not consistent because some justices are charged with plotting a liberal constitutional course, others are charged with plotting a conservative constitutional course, and a few, most notably Justice Kennedy ${ }^{325}$ receive ambiguous signals from their appointment and confirmation process. ${ }^{326}$ Judicial missions are not self-conscious because no faction intended the contemporary course of judicial decision making and the balance of power on the Court reflects the timing of judicial vacancies rather than longstanding political decisions to move constitutional law in a specific direction. ${ }^{327}$ Judicial missions are not relatively public because the course of judicial decision making often depends on tiebreaking votes cast by idiosyncratic justices. ${ }^{328}$

Judicial supremacy is not hardwired into the state of polarized parties and divided government. ${ }^{329}$ Although the structure of partisan competition generates judicial power, the present constitutional order cannot generate particular courses of judicial decision making that are traceable to consistent, self-conscious, and relatively public decisions made by a stable group of politically accountable governing elites. ${ }^{330}$ Judicial power remains rooted in the structure of constitutional politics. ${ }^{331}$ The tendency for all presidents to nominate judicial activists combined with political incapacity to alter any course of judicial decision making leaves the Supreme Court with the last word on numerous constitutional issues by default. ${ }^{332}$ In sharp contrast to the long state of courts and parties, however, no distinctive course of judicial decision making is hardwired into the long state of polarized parties and divided government. The course of judicial decision making depends on which party won the last election, which elections that party won, and whether judges are able to time their leaving the bench to ensure their replacement will be appointed by a President who shares their constitutional vision. ${ }^{333}$ Fisher and Whole Woman's Health would have been

322. See supra Part III.

323. See id.

324. See id.

325. See supra note 286 and accompanying text.

326. See supra Part III.

327. See id.

328. See id.

329. See id.

330. See id.

331. See id.

332. See id.

333. See id. 
decided differently if Justice Ginsburg had predeceased Justice Scalia or Democrats in 2012 and 2014 would have gained control of Congress, but lost control of the White House. ${ }^{334}$ Conservative opponents of same-sex marriage appropriately blame Justice Kennedy's post-appointment embrace of gay rights ${ }^{335}$ and have reason to hope that random occurrences within the present constitutional order such as a major Clinton scandal will give them the opportunity to place a justice on the bench who will cabin or reverse Obergefell v. Hodges. A course of constitutional decisions so based on historic accidents hardly merits the finality due to judicial rulings rooted in relatively enduring features of a constitutional order.

The Supreme Court's course of decision making in the wake of Justice Scalia's death suggests that some justices may have acknowledged the limitations on judicial power in the state of polarized politics and divided government. The justices in 2016, when adjudicating the major cases before them, decided as little as was constitutionally possible. Justice Kennedy's majority opinion in Fisher emphasized the distinctive character of the race-conscious program adopted by the University of Texas School of Law when sustaining that affirmative action policy. ${ }^{336}$ Justice Breyer's majority opinion in Whole Woman's Health left open the constitutionality of restrictions on abortion that medical evidence indicates may have health benefits. ${ }^{337}$ No opinion casts doubt on past assertions by Roberts Court justices that the Supreme Court has the final authority on the meaning of the Constitution. ${ }^{338}$ Nevertheless, Fisher and Whole Woman's Health provide some hope for thinking that the justices understand that courts should be modest in their ambitions when the structure of partisan conflict prevents them from being supreme. ${ }^{339}$

334. See supra notes $274-80$ and accompanying text.

335. See, e.g., Marc A. Greendorfer, After Obergefell: Dignity for the Second Amendment, 35 Miss. C. L. REV. 1, 3-7 (2016).

336. 136 S. Ct. 2198, 2208 (2016) (explaining "the University's program is sui generis").

337. 136 S. Ct. 2292, 2298 (2016) (noting "the virtual absence of any health benefit" from the state regulations of abortion clinics).

338. See generally City of Boerne v. Flores, 521 U.S. 507 (1997).

339. For the normative claim that judicial modesty appropriate during the state of polarized parties and divided government, see Graber, The Coming Constitutional Yo-Yo?, supra note 10, at 717-18. 